University of South Florida

DIGITAL COMMONS

Digital Commons @ University of

@ UNIVERSITY OF SOUTH FLORIDA

South Florida

$1-1-2009$

\title{
2009 Annual Report USF Polytechnic
}

USF

Follow this and additional works at: https://digitalcommons.usf.edu/usf_accountability_reports

\section{Scholar Commons Citation}

USF, "2009 Annual Report USF Polytechnic" (2009). USF Accountability Reports. 1.

https://digitalcommons.usf.edu/usf_accountability_reports/1

This Article is brought to you for free and open access by the USF Archives at Digital Commons @ University of South Florida. It has been accepted for inclusion in USF Accountability Reports by an authorized administrator of Digital Commons @ University of South Florida. For more information, please contact digitalcommons@usf.edu. 


\section{Florida Board of Governors State University System (SUS) Annual Report}

\section{University of South Florida-Polytechnic}

Approved by the USF Board of Trustees

December 16, 2009 


\section{$\underline{\text { Data Definitions }}$}

\section{GOAL 1:}

- Baccalaureate Degrees Awarded and Graduate Degrees Awarded: Graduate degrees include master's, research doctoral, and professional doctoral programs. Source: SUS Student Instruction File

\section{- \# and \% Baccalaureate Degrees Awarded (Non-Hispanic Blacks and Hispanics):} The number of baccalaureate degrees granted to non-Hispanic black students or Hispanic students. The percentage is the number of baccalaureate degrees awarded to each group divided by the total number of degrees awarded, excluding those awarded to non-resident aliens and those not reporting race/ethnicity. Source: SUS Student Instruction File

- \# and \% Baccalaureate Degrees Awarded (Pell Recipients): The number of baccalaureate degrees awarded to federal Pell grant recipients, an indicator of low family income. For this report, a Pell grant recipient is defined as a student who received Pell within six years of graduation. The percentage is the number of baccalaureate degrees awarded to Pell recipients as listed above divided by the total number of degrees awarded, excluding those awarded to non-resident aliens. Sources: SUS Student Instruction File and Student Financial Aid File

\section{GOAL 2:}

- \# Degrees Awarded in Select Areas of Strategic Emphasis: Degrees as reported above by six-digit Classification of Instruction Program. The areas of strategic emphasis were selected by the Board of Governors staff in consultation with business and industry groups.

- Pass Rates on Professional Licensure Examinations: Many professional licensure data, gathered by the respective licensing boards and housed within the Department of Business and Professional Regulation, are not currently formatted and do not contain sufficient information to match to SUS data. Board of Governors staff will work with individuals from the appropriate agencies to try to get data in the needed format.

\section{GOAL 3:}

- Federally Financed and Total Academic Research and Development Expenditures: The National Science Foundation conducts an annual survey of colleges and universities regarding research and development expenditures. These amounts combine reported science and engineering R\&D expenditures with reported nonscience and engineering expenditures. Dollars are in nominal dollars (i.e., not inflationadjusted). Source: http://webcaspar.nsf.gov/ 
- \# Licenses/Options Executed: Count of the number of licenses/options executed in the fiscal year for all technologies. Each license agreement is counted separately. Source: AUTM Licensing Survey

- Licensing Income Received: License issue fees, payments under options, annual minimums, running royalties, termination payments, amount of equity received when cashed-in, and software and biological material end-user license fees of $\$ 1,000$ or more, but not research funding, patent expense reimbursement, valuation of equity not cashed-in, software and biological material end-user license fees of less than $\$ 1,000$, or trademark licensing royalties from university insignia. Source: AUTM Licensing Survey

\section{$\underline{\text { RESOURCES, EFFICIENCIES, AND EFFECTIVENESS }}$}

\section{- 6 -Year Graduation and Retention Rates (FTICs), 4-Year Graduation and Retention Rates (AA Transfers), 5-Year Graduation and Retention Rates (Other Transfers): An} FTIC cohort is defined as undergraduates entering in fall term or summer continuing to fall with fewer than 12 hours earned since high school graduation. An AA Transfer cohort is defined as undergraduates entering in fall term or summer continuing to fall and having earned an AA degree from an institution in the Florida College System. An Other Transfer cohort is defined as undergraduates entering in fall term or summer continuing to fall who are not FTICs or AA transfers. The rate is the percentage of the initial cohort that had either graduated from or was still enrolled in the sixth academic year for FTIC students, fourth year for AA Transfers, and fifth year for Other Transfers. Both full-time and part-time students are included in the calculation. Source: SUS Retention File

- Student-Faculty Ratio: The ratio of full-time equivalent students (full-time plus 1/3 part time) to full-time equivalent instructional faculty (full time plus $1 / 3$ part time). In the ratio calculations, exclude both faculty and students in stand-alone graduate or professional programs such as medicine, law, veterinary, dentistry, social work, business, or public health in which faculty teach virtually only graduate-level students. This metric does not count undergraduate or graduate student teaching assistants as faculty. Source: Common Data Set/IPEDS

- Funding per FTE Student: E\&G appropriation and tuition revenues are divided by total student FTE. Only state-fundable credit hours are used. To allow for national comparisons, FTE for this metric uses the standard IPEDS definition of FTE, equal to 30 credit hours for undergraduates and 24 for graduates. Sources: Operating Budget, SUS Student Instruction File 


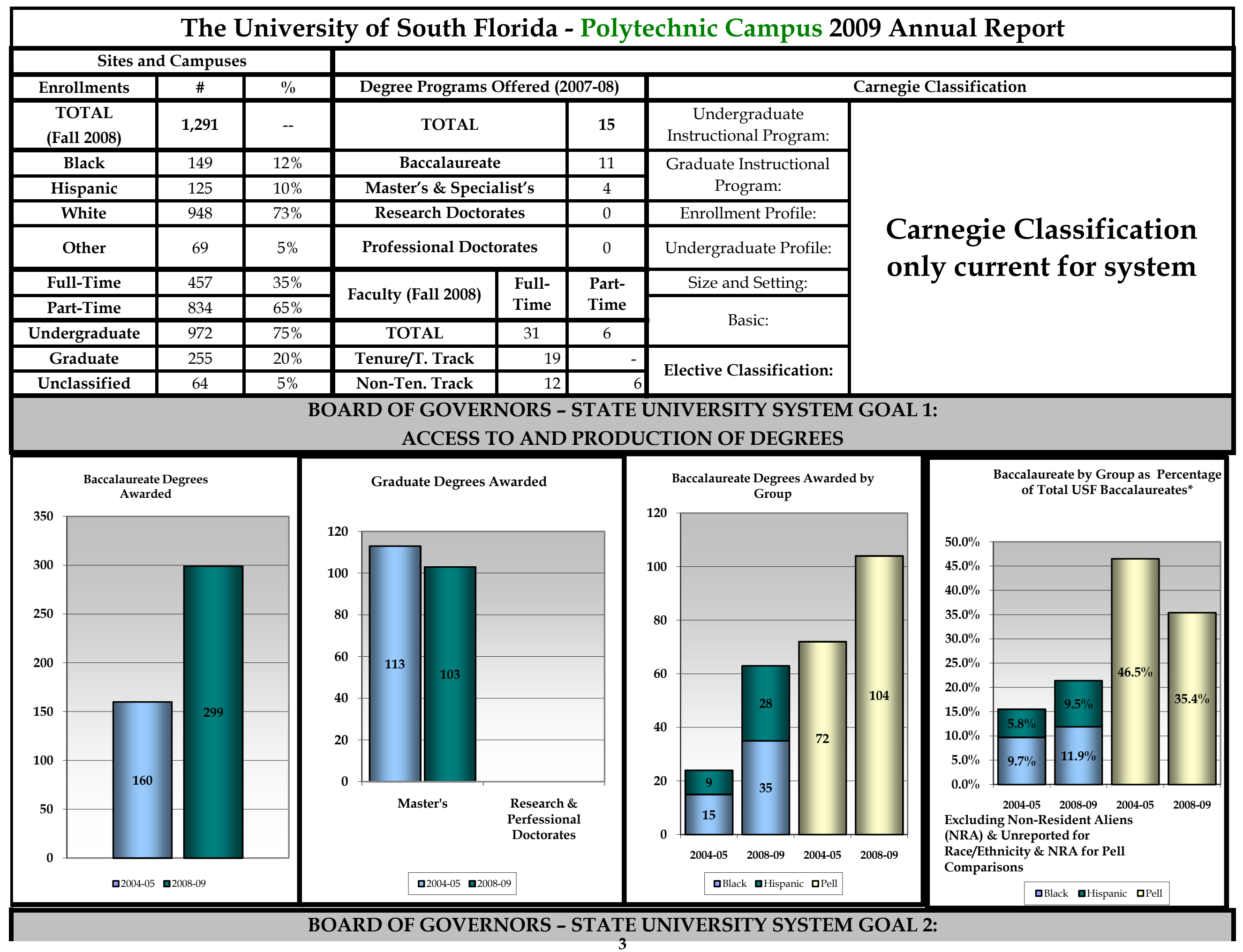




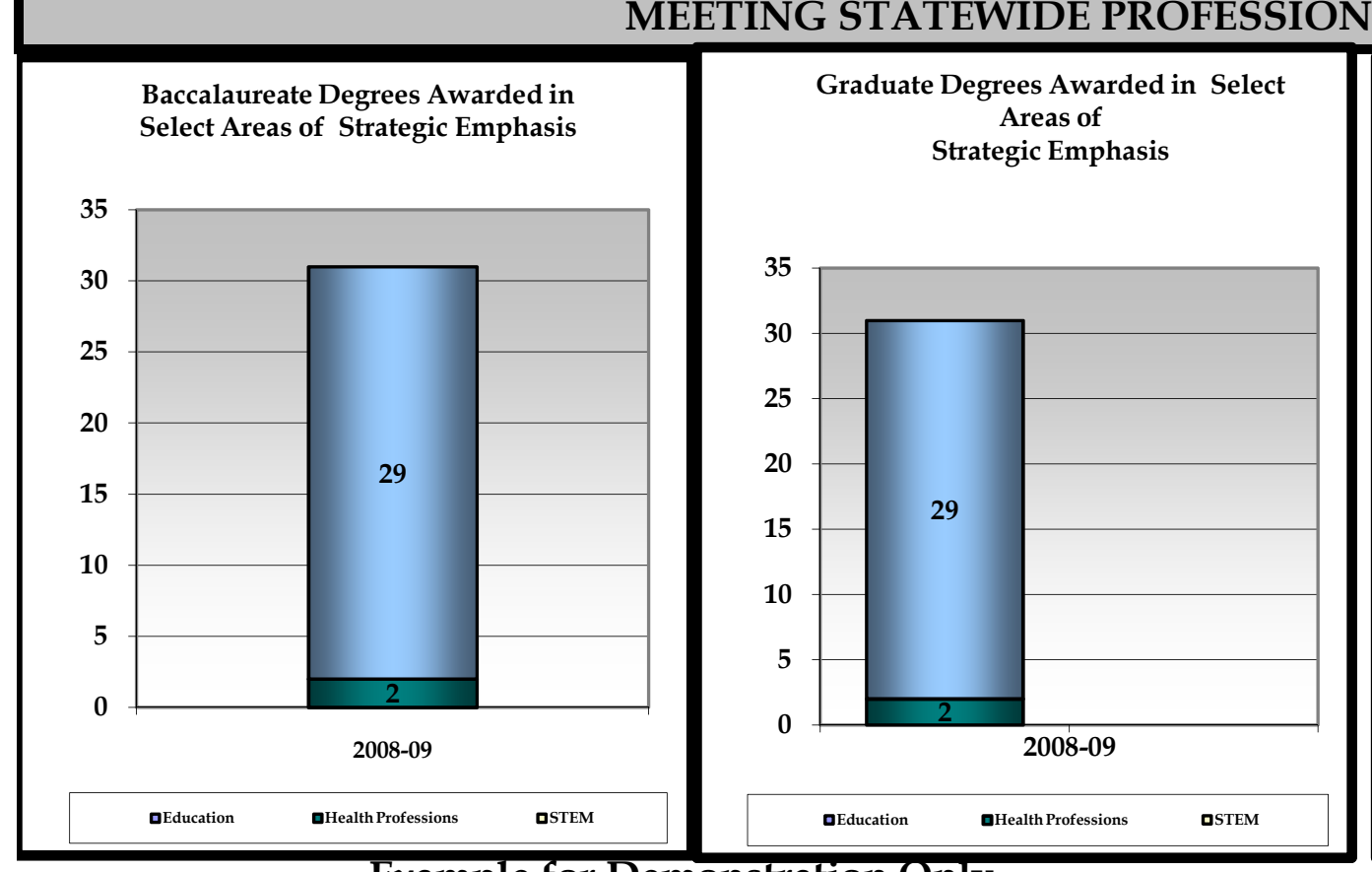

Example for Demonstration Only.

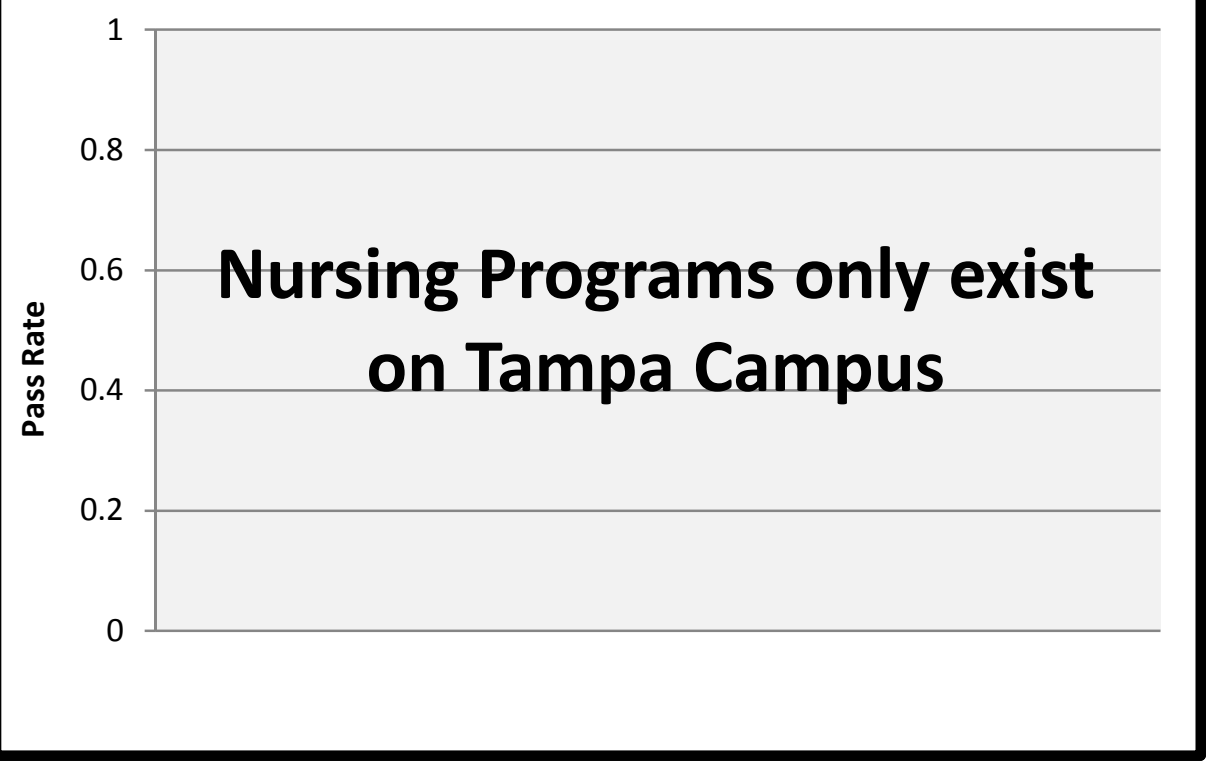

See ENDNOTES Regarding Pass Rates.

BOARD OF GOVERNORS - STATE UNIVERSITY SYSTEM GOAL 3:

BUILDING WORLD-CLASS ACADEMIC PROGRAMS AND RESEARCH CAPACITY

Academic Research and Development

Expenditures

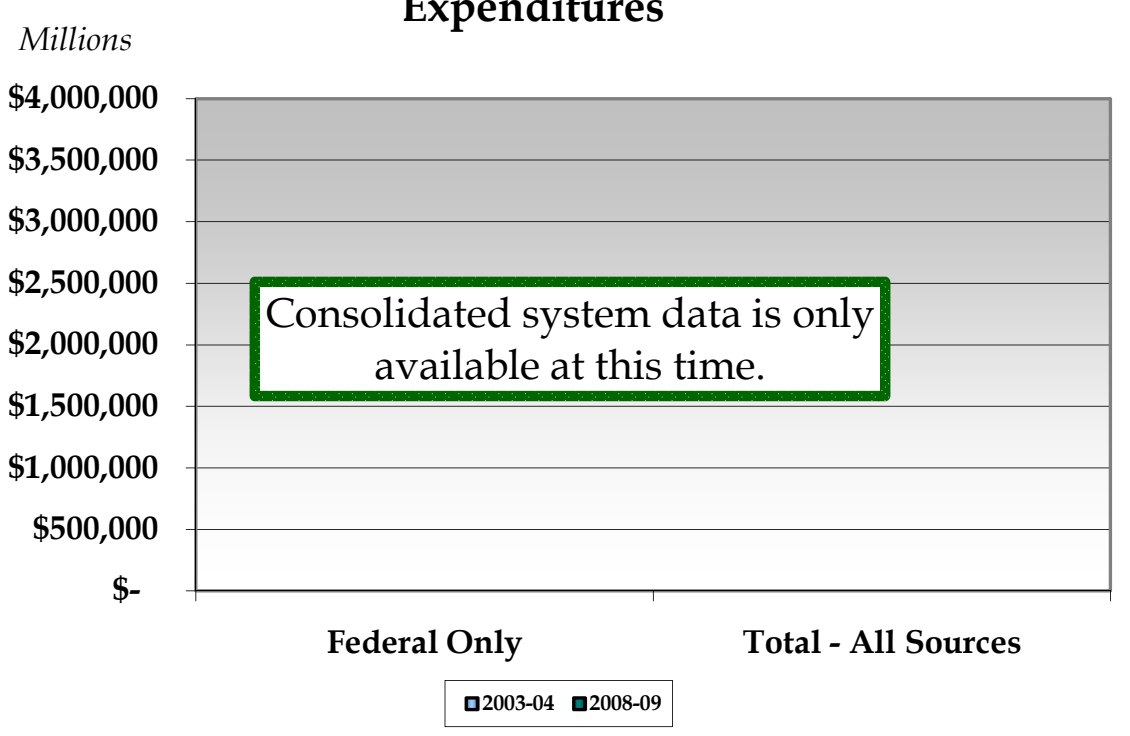

University Innovations Generating Revenue Through Technology Transfer:

Licenses and Licensing Revenue

Millions

$\$ 1,000,000$

$\$ 900,000$

$\$ 800,000$

$\$ 700,000$

$\$ 600,000$

$\$ 500,000$

$\$ 400,000$

$\$ 300,000$

$\$ 200,000$

$\$ 100,000$

$\$ 0$

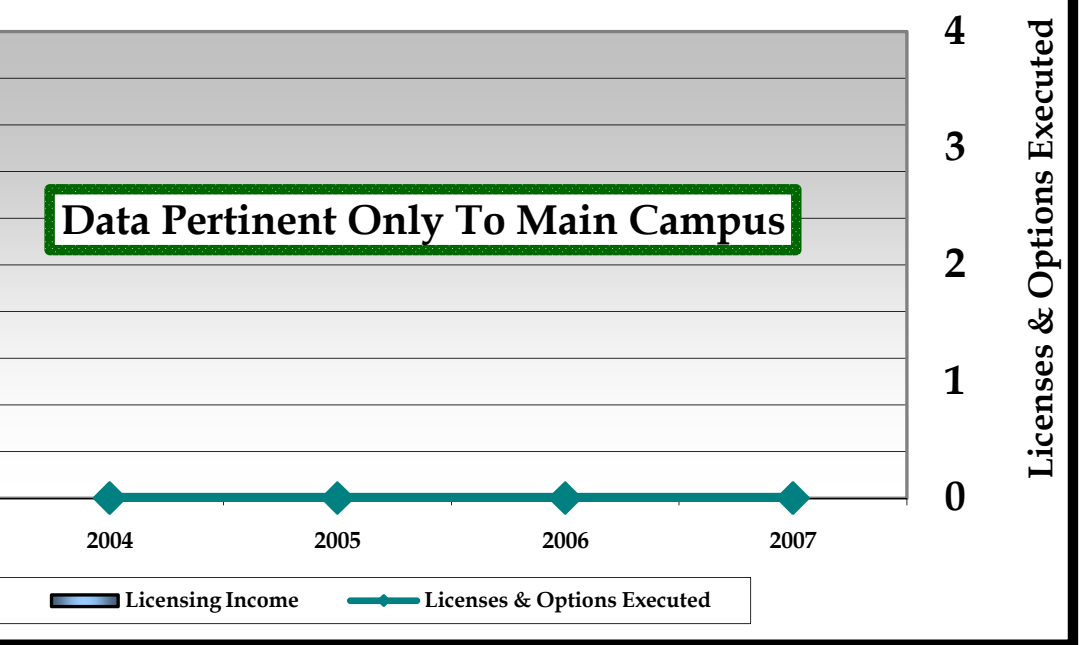


Key University Achievements [Include a maximum of three in each category.]

\section{- Student awards/achievements}

Increasing student co-curricular programs and activities is a strategic goal. The Student Affairs unit was established, a comprehensive unit providing integrative services designed to enhance student learning and engagement. Student Affairs is comprised of Recruitment, Orientation, Enrollment Management, Admissions, Registration and Records, Financial Aid, Pre-Major Advising, Multicultural Education and Engagement Programs, Student Learning Success Programs, Personal and Career Counseling, Service Learning and Cooperative Internships, Residential Life, Wellness and Recreation, Student Rights and Responsibilities, Student

Leadership and Engagement Programs.

Sixty student activity events (average of 5 events per month) were provided with attendance of 100-400 faculty, staff, and students at each event. The number of student activity events represents an increase of $25 \%$ from 2007 to 2008 . Students who attended events on campus reported a $97 \%$ satisfaction rate with those events. Seven student organizations have developed and been supported by Student Affairs.

Focusing on student support and success, USF Polytechnic sponsors 12 campusbased scholarships. A Transfer Success course was developed to promote academic success and persistence, encourage student engagement on campus, provide opportunities to collaborate with college personnel and develop self-directed learning and responsibility. The Polytechnic Leadership Society was established to assist student development of leadership skills, networking with community leaders and serving as official student representatives of the university in varying on- and off-campus activities and events.

\section{- Faculty awards/achievements}

Dr. John Selsky, Associate Professor, Management, was appointed to an Associate Fellowship in the Institute for Science, Innovation and Society, University of Oxford, Said School of Business.

Faculty Tenured: Dr. Paul Bao, Associate Professor, Dr. Alessio Gaspar, Associate Professor and Dr. Richard Plank, Associate Professor

\section{- Program awards/achievements}

The Information Technology Program has increased student credit hour production by $82.6 \%$ from 2007-2008 to 2008-2009. The program hosted five student interns from Polytech Marseille, The University of Provence Aix-Marseille, in summer 2009. Internships focused on research in information technology applications in industrial engineering and informatics. The Information Technology Program also hosted faculty researchers from Vinh University, Vietnam.

\section{- Research awards/achievements}

Increasing grant activity is a strategic goal. In 2007-2008 three grant proposals were submitted, totaling $\$ 1,080,647$. In 2008-2009 six grant proposals were submitted, totaling $\$ 3,079,347$.

In 2007-2008 one grant was awarded, totaling \$56,717. In 2008-2009 four grants were awarded, totaling \$892,124 including $\$ 646,954$ in federal funding.

\section{Institutional awards/achievements}

USF Polytechnic has shattered campus fund-raising records, booking over $\$ 15$ million in matchable gifts (for a total of $\$ 30$ million) and also registering a 95\% participation rate during its annual Faculty Staff Campaign.

USF Polytechnic has seen a dramatic increase in its media placements and had one particular story of international significance published in 150 media outlets.

USF Polytechnic's I-4 campus is being developed as a unique "bioscape," designed by worldrenowned architect, Dr. Santiago Calatrava. The campus context will emerge as an unprecedented synthesis of architecture, design, engineering, agriculture and sustainability - a living example of the research, academic and social missions of USF Polytechnic. 
Community engagement is a core value. USF Polytechnic serves as a key resource for communities and seeks collaborative partnerships to enhance civic, social, educational and economic development. In 2008 the Central Florida Development Council, a USF Polytechnic partner, commissioned a study of the region's current economic strengths and opportunities. SRI International, an independent research firm, conducted a "cluster analysis" study, identifying seven industry sectors that were already represented in the regional economy and primed for future cultivation and growth: 1) research \& engineering services; 2) logistics \& supply chain management; 3) life science \& medical services; 4) education \& government; 5) construction \& real estate; 6) business \& financial services; and 7) agriculture \& agritechnology. The study provides a framework for programmatic development at USF Polytechnic (see Contextual Introductory Comments below).

USF Polytechnic has nurtured a dynamic partnership with community stakeholders, with a particular emphasis on economic development partners. These partnerships have resulted in joint development trips to Washington, D.C., Austin, TX, Nashville, TN, and Europe, as well as extensive collaboration on regional priorities within Florida.

USF Polytechnic provided substantial technical and strategic support for regional restructuring and visioning. USF Polytechnic was instrumental in the restructuring and relaunching of Lakeland Vision, one of the state's most established community visioning organizations. USF Polytechnic was instrumental in board development, organizational design and strategic implementation as Lakeland Vision updated its 10-year plan. USF Polytechnic organized and hosted a regional summit on renewable energy, an effort that has an ongoing impact on economic development and advocacy strategies in central Florida. 


\section{Undergraduate Retention and Graduation Rates}

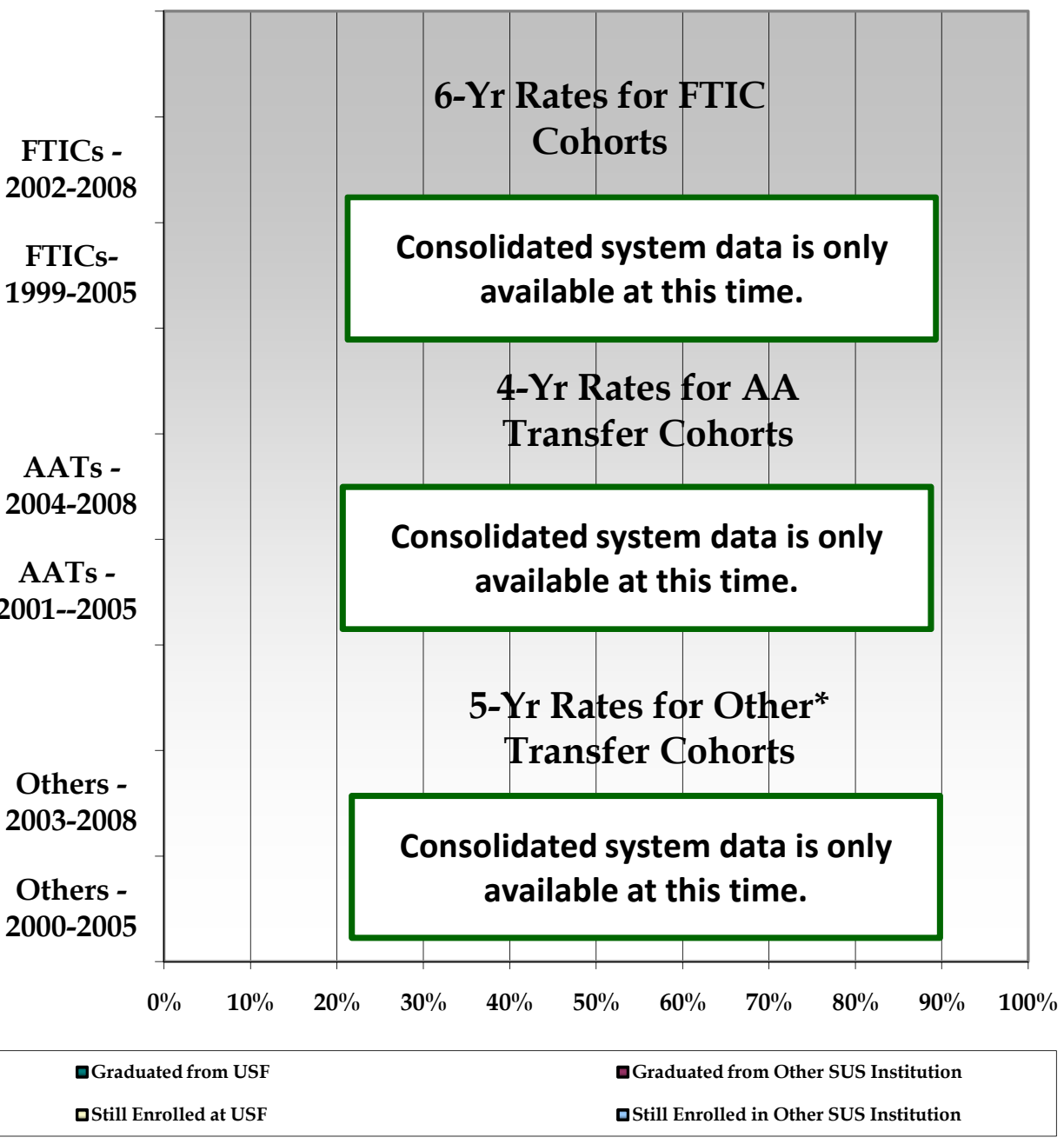

* The composition of "Other Transfer" cohorts may vary greatly by institution.
Student-to-Faculty Ratio

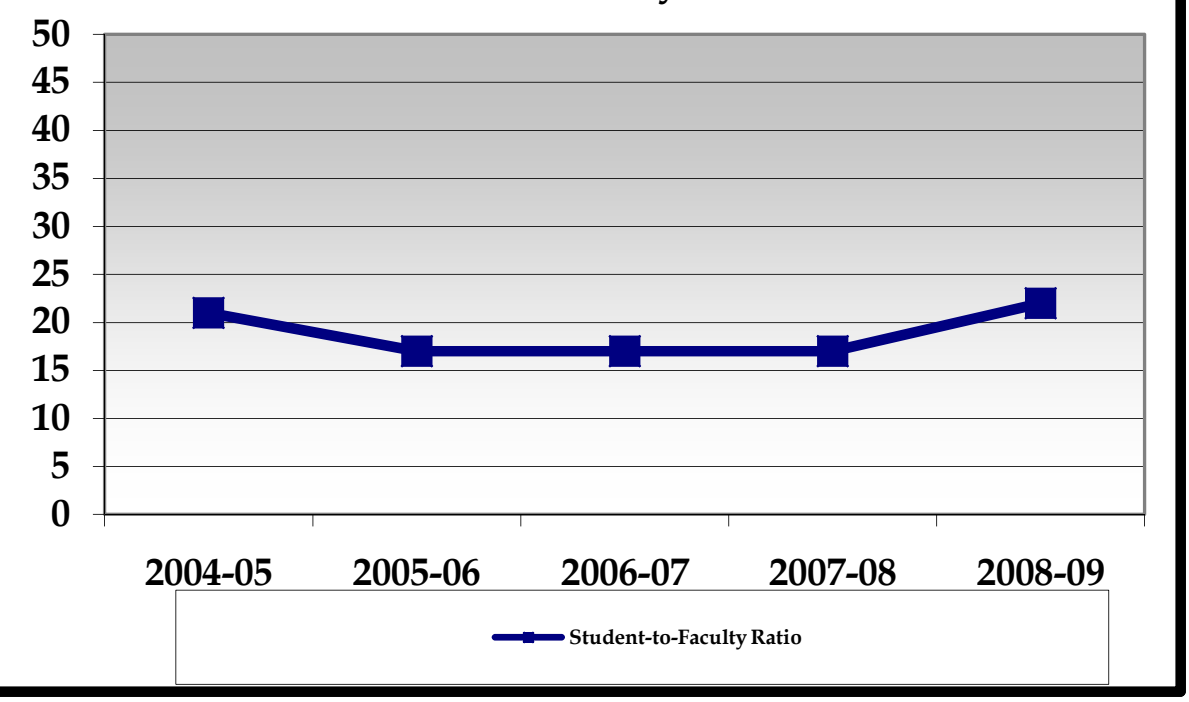

\section{Funding Per Student FTE**}

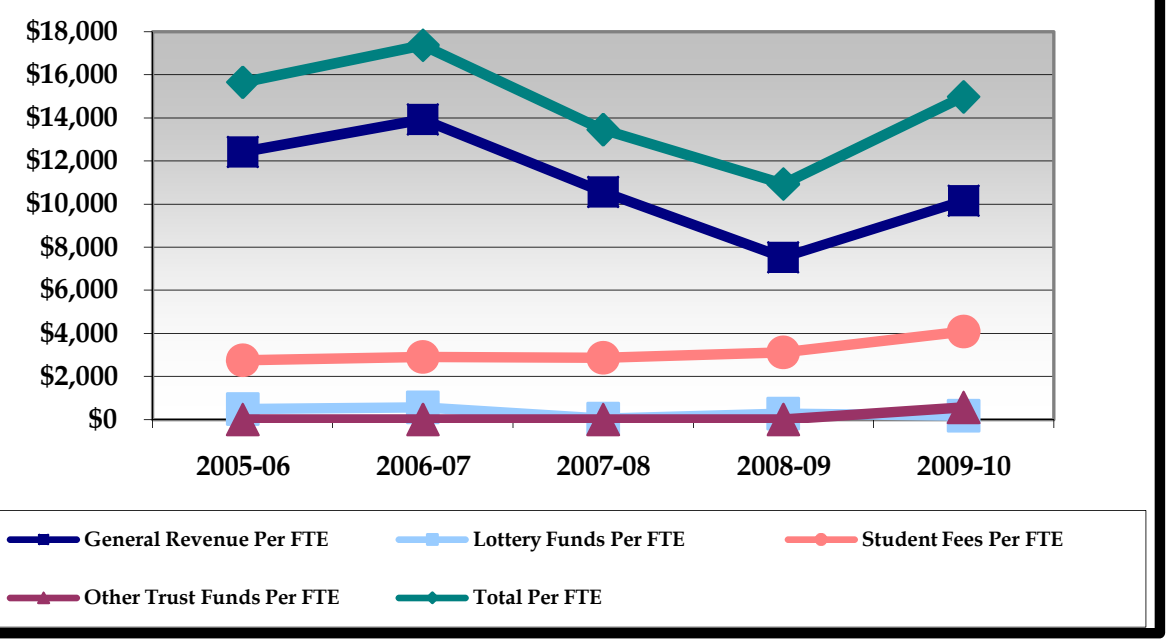

** FTE for this metric uses the standard IPEDS definition of FTE, equal to 30 credit hours for undergraduates and 24 for graduates. 


\section{$\underline{\text { Introduction }}$}

\section{- Mission}

The University of South Florida Polytechnic is committed to excellence in interdisciplinary and applied learning; to the application of cutting-edge research and technology to real world needs; and to collaborative partnerships that support economic, social, and community development.

http://www.poly.usf.edu/AboutUs/StrategicPlan.html

\section{- Vision}

The University of South Florida Polytechnic will be a premier destination campus for applied learning, research and innovative technology. Our students and graduates will inspire and lead change, locally and internationally. http://www.poly.usf.edu/AboutUs/StrategicPlan.html

\section{- Other Contextual Introductory Comments}

The University of South Florida's vision for its youngest campus - the University of South Florida Polytechnic - evolves in a context of several parallel dynamics, all of which converge at the heart of Florida's High Tech Corridor, in Lakeland. These dynamics include the demographic pressures within the state of Florida, economic development factors impacting central Florida as well as a broader context and the maturation of the USF System.

Florida remains one of the states that demographers project as a high growth state in the coming decades. This growth is a factor of inmigration from cooler climates to the north as well as immigration from Mexico, Central and South America and the Caribbean. The resulting growth is already impacting the way the region is perceived: the widely cited economist and futurist, Richard Florida, has identified the Miami-Orlando-Tampa corridor as one of 40 "megaregions that drive the world economy."
The state's economy has historically been driven by agriculture, tourism and real estate. Under Governor Jeb Bush, however, Florida designated its emerging core, anchored by I-4, as "Florida's High Tech Corridor." The FHTC's establishment has helped to focus those inside and outside the state on the tremendous potential of technology-driven economic development within Florida.

In 2008, the Central Florida Development Council hired SRI International, an independent research firm, to conduct a detailed analysis of the region's current economic strengths and opportunities. The resulting "cluster analysis" study identified seven industry sectors that were already represented in the regional economy and primed for future growth: research \& engineering services; logistics \& supply chain management; life science \& medical services; education \& government; construction \& real estate; business \& financial services; and agriculture \& agritechnology. As the region's public and private sectors mobilize to cultivate and exploit the industry clusters identified in the SRI International cluster study, USF Polytechnic has aligned the institution's design with its socio-economic context, providing a distinct focus for the development of academic programs. Each of the industry clusters maps directly to specific academic programs available or proposed for future development at USF Polytechnic.

As the USF System has evolved, it has dramatically expanded access to Florida residents and highly motivated students from around the world. The diversity of its four campuses will continue to accommodate the development of distinctive models of higher education - what the USF Board of Trustees has described as "mission differentiation" - to serve the current and emerging education, research and economic development needs of the state, nation and world.

While the polytechnic model itself is not new, it is relatively new to the southeastern United States - and thoroughly novel to Florida's public higher education system. The word "polytechnic" is derived from a Greek term which translates, literally, as "skilled in many 
arts." As implemented by USF Polytechnic, a "polytechnic" education is peculiar in method as well as substance. In other words, polytechnics are distinguished both in what they do and how they do it. USF Polytechnic will also be distinguished contextually, as it develops an extraordinary campus environment at its new campus site.

Methodologically, polytechnics focus on applied, multi-disciplinary learning and research. Learning environments are created to facilitate hands-on, collaborative problem solving and inquiry. Learning experiences include problem-based applications, field experiences, practica and internships. Rather than basic, theoretical research, polytechnics focus on the practical application of existing knowledge to solve tangible problems and provide tangible social benefits. Rather than reifying the "silo" paradigm so common in American higher education, polytechnics orient scholarship collaboratively in a relentless pursuit of cross-disciplinary synergies and innovation. The academic infrastructure of USF Polytechnic reflects this new paradigm with interdisciplinary colleges: Applied Arts and New Media; Human and Social Sciences; and Technology and Innovation. Substantively, polytechnics tend to cultivate strengths in the applied scientific and professional fields, such as engineering, sciences, business and education. Traditional "liberal arts" disciplines are not absent from the curriculum but are often delivered within the context of the general education curricula and embedded in the multidisciplinary, applied discovery characteristic of the polytechnic experience.

Contextually, USF Polytechnic's I-4 campus is being developed as a unique "bioscape," designed by world-renowned architect, Dr. Santiago Calatrava. The campus context will emerge as an unprecedented synthesis of architecture, design, engineering, agriculture and sustainability - a living example of the research, academic and social missions of USF Polytechnic.

\section{BOARD OF GOVERNORS - STATE UNIVERSITY SYSTEM GOAL 1: ACCESS TO AND PRODUCTION OF DEGREES}

From AY 2007-2008 to 2008-2009 upper-level undergraduate FTE increased by $10.58 \%$ from 596 to 757 . Grad I FTE increased by $1.34 \%$ from 112 to 134 during the same period.

From AY 2004-2005 to 2009-2009 the percentage of undergraduate students who applied for admission to USF Polytechnic, were accepted and then enrolled in courses increased from $66.03 \%$ to $77.19 \%$. The percentage of graduate students who applied for admission to USF Polytechnic, were accepted and then enrolled in courses increased from $70 \%$ to $74 \%$.

The number of bachelor's degrees awarded in the same time period increased from 160 to 298. The time to degree decreased from 3.49 years to 2.64 years. The average undergraduate GPA increased from 2.99 to 3.10. The number of master's degrees awarded decreased slightly from 113 to 101 . The time to degree decreased from 1.91 years to 1.64 years. The average graduate GPA increased from 3.78 to 3.80 .

Goal 2 of USF Polytechnic Strategic Plan aligns closely with the SUS Goal 1: Recruit students locally, nationally, and internationally who are prepared for a polytechnic learning environment, and provide programs and opportunities that enhance student retention and academic, personal, and professional success. During 2009-2010, the following strategies are targeted:

\section{Access}

- Continue to increase student enrollment and implementation of a comprehensive enrollment management plan for marketing, recruitment, admissions, advising, retention and graduation of diverse and high quality students. Include an information plan for middle schools and high schools to be implemented in spring 2010.

- Increase scholarships available for students. 


\section{GOAL 1: ACCESS TO AND PRODUCTION OF DEGREES}

(Continued)

\section{Retention}

- Create opportunity for student participation in honor societies and academic award programs.

- Continue to increase comprehensive student life activities to include academic and technology extra- and co-curricular activities; social and community engagement opportunities; and personal, academic and career support services.

- Identify funding sources for the development of a student dormitory on the new campus.

\section{Student Success and Degree Completion}

- Continue to develop student leadership, mentoring and learning community programs to contribute to student success and create a sense of belonging to USF Polytechnic.

- Enhance advising to increase retention and ensure timely completion of degree programs.

- Develop a system for tracking graduates and establish USF Polytechnic alumni affiliation.

\section{BOARD OF GOVERNORS - STATE UNIVERSITY SYSTEM GOAL 2: MEETING STATEWIDE PROFESSIONAL AND WORKFORCE NEEDS}

In AY 2008 and 2009 emphasis was increased on internship, practica and field experiences/service learning opportunities for students, e.g., IT senior projects engaging with local businesses or government agencies; establishment of an IT practicum featuring students working in small teams on practical, real-world problems of value to the campus.

New concentrations in the Bachelor of Science in Applied Science were targeted for development: Nutrition, Entrepreneurship, Supply Chain Management, Leadership Studies, and Multicultural Leadership.

The Department of Information Technology converted its fixed curriculum to a student-defined/department-approved program of study, providing additional flexibility to better adapt to the rapidly changing world of information technology and providing incentive for student performance. Students with exemplary performance in an advised cluster of courses are awarded a Certificate of Specialization. Two initial certificates have been established - Information Security and Web Development. Two new specialized clusters of courses are in development - health informatics and mobile device applications.

Goal 3 of USF Polytechnic Strategic Plan aligns closely with the SUS Goal 2: Expand and create academic programs that focus on applied learning, applied research, applied technology, and interdisciplinary approaches in a polytechnic model. Develop and implement new degree programs in five areas of distinction: applied health sciences; mathematics and science education; business and entrepreneurship; manufacturing engineering and technology; and information technology. During 2009-2010, the following strategies are targeted:

- Submit substantive change approval request to SACS for lowerdivision enrollment approved by the USF Board of Trustees and the Board of Governors in September 2008 
GOAL 2: MEETING STATEWIDE PROFESSIONAL AND WORKFORCE NEEDS (Continued)

- Submit SACS Initial Application for Accreditation in February 2010

- Develop new degree program concepts to enhance the "polytechnic" curriculum in the five areas of distinction and aligning with the industry sectors identified in the SRI International cluster study. Examples of program concepts to be developed are: M.S. Information Technology, B.A. Digital Arts \& Digital Media, B.S. Communication Sciences \& Technologies, B.S. Interdisciplinary Engineering, B.S. Manufacturing Engineering Technology, M.S. Manufacturing Engineering, Pre-Pharmacy Program, B.S. Medical Technologist, B.S. Agricultural \& Biological Engineering, B.A. Architecture, B.A. Design, B.S., M.Ed. Integrated STEM Education (Elementary Track, Secondary Track), B.S., M.Ed. Technology-Mediated Learning, B.S. Forensic Science/Studies.

- Continue to partner with community stakeholders and economic development partners to provide technical and strategic support for regional restructuring and visioning.

\section{BOARD OF GOVERNORS - STATE UNIVERSITY SYSTEM GOAL 3: BUILDING WORLD-CLASS ACADEMIC PROGRAMS AND RESEARCH CAPACITY}

Information Technology continues to be central to the development of USF Polytechnic. Three research projects at USF Polytechnic illustrate the capacity of information technology as an interdisciplinary driver in the region: the Center for the Development of Information Technology Applications for Manufacturing and Distribution (CITA), Computing Education Research at Lakeland (CEReAL), and Linux Integration Networking Connections (LINCS).

CITA operates as a partnership between the University of South Florida Polytechnic and the local business/industry community. An interdisciplinary team of USF Polytechnic faculty and staff representing the academic divisions of Information Technology, Engineering and Business/Innovation Management have worked with current and emerging regional manufacturing, warehousing and distribution industries to further the development of technology applications, professional development systems and post-secondary programs in the area of Information Technology. The project is funded by a U.S. Small Business Administration Congressional Earmark grant.

CEReAL is an interdisciplinary research group, actively promoting and conducting research in advanced pedagogical techniques for teaching computing to undergraduates. Its members have been prolific in conference and journal publications, and effective in obtaining federal funding to support their research and the development of infrastructure and Information Technology curricula.

LINCS is a joint NSF grant (with Polk State College) awarded in 2008 for a three-year term. This project is developing an innovative 4-year online curriculum in Linux System Administration, emphasizing pervasive use of advanced pedagogical methods. The curricular design is dual tracked for both BSIT and AS-BSAS students. 


\section{GOAL 3: BUILDING WORLD-CLASS ACADEMIC PROGRAMS AND RESEARCH CAPACITY (Continued)}

Goal 4 of USF Polytechnic Strategic Plan aligns closely with the SUS Goal 3: Implement the Campus Master Plan and develop a campus infrastructure to support a polytechnic learning and research environment, and develop a stable economic base for continued campus and program development as a polytechnic campus. Develop collaborative public and private partnerships that enhance funding opportunities, including leveraging state and federal funding. During 2009-2010, the following strategies are targeted:

- Increasing faculty capacity and numbers of faculty with polytechnic experience and research profiles, including deans for the Colleges of Technology and Innovation and Human and Social Sciences, and a director for the emerging Division of Applied Arts and New Media.

- Increasing faculty grant capacity by providing staff support in grant writing, grant accounting and management.

\section{BOARD OF GOVERNORS - STATE UNIVERSITY SYSTEM GOAL 4: MEETING COMMUNITY NEEDS AND FULFILLING UNIQUE INSTITUTIONAL RESPONSIBILITIES}

The establishment of the Extended University unit in AY 2008-2009 provided for coordination and development of distributed education at USF Polytechnic. The unit comprises three departments: Distance Learning, Extended Education, and Classroom Technology \& Media Services. Distance Learning administers online programs and courses, is responsible for management of Blackboard functions on the campus, and supports the development and delivery of web-based courses. Extended Education serves as the center of lifelong learning by providing innovative training and personal enrichment opportunities for students, faculty, businesses, community and international partners. Classroom Technology \& Media Services provides numerous services to support classroom instructional technology, media services and production. The department also provides faculty training and support in the application of new classroom technologies.

The USF Polytechnic Summer Gifted and Talented Program is coordinated through Extended University. The program features two high-tech, high-engagement learning experiences: Hot2Bot and Sci-Fi High. Seventy-three percent of the participants in summer 2008 and fifty-three percent of the participants in summer 2009 were economically disadvantaged and were able to attend the program through donor-generated scholarships.

International cooperative partnerships for education and faculty research exchange are also been coordinated through Extended University. Partnerships have been developed with education institutions and government agencies in El Salvador (Escuela Americana and FEPADE); France (Euromed and Polytech Marseille); Finland (Turku University of Applied Sciences); the Netherlands (Avans University of Applied Sciences); and Vietnam (Vinh University). 


\section{GOAL 4: MEETING COMMUNITY NEEDS AND FULFILLING UNIQUE INSTITUTIONAL RESPONSIBILITIES (Continued)}

Goal 5 of USF Polytechnic Strategic Plan aligns closely with the SUS

Goal 4: Develop collaborative public and private partnerships that enhance funding opportunities, including leveraging state and federal funding.

During 2009-2010, the following strategies are targeted:

- Continue to establish mutually beneficial partnerships, including international cooperative agreements, to enhance campus development opportunities.

- Continue to develop Extended Education programming.

- Open a business incubator and accelerator in fall 2009.

- Enhance the campus infrastructure for advancement and development.

- Strengthen the Alumni Organization in the central Florida region and promote Alumni affinity with USF Polytechnic.
Additional Information on Quality, Resources, Efficiencies, and

\section{Effectiveness}

USF Polytechnic is committed to Public Service Outreach as exemplified in the following:

- The Rath Senior ConNEXTions and Education Center provides community partnerships, collaboration and education, addressing elder needs and lifelong learning. The center provides support for student internships and opportunity for faculty to conduct research at the center. The Rath Center currently facilitates four education and support groups: the Alzheimer's Disease/Dementia Caregiver Support Group, the Beginning Alzheimer's Support and Education (BASE), the Beyond BASE: Mild Cognitive Impairment/Early State Dementia Support and Education Group, and the Parkinson's Disease Support Group.

- USF Polytechnic's Entrepreneurship and Ventures Planning unit provides direction, coordination and facilitation of opportunities for faculty, students, staff and community to engage in restructuring and development, technology and market assessment, technology commercialization, new venture formation and new venture financing activities. The establishment of BlueSky, a business incubator and accelerator, is a key focus of this unit for 2009-2010.

- The USF Polytechnic Reading Clinic provides tutoring in reading and writing for elementary school children and opportunity for master's degree students to tutor and receive mentoring from faculty. The Polk County Reading Council, a consortium of school-based reading specialists, was also established.

- Collaboration among the USF Polytechnic Dean of Students, Division of Education faculty and Polk County Schools resulted in the development of the S.T.A.R.T. (Student Teaching And Role-modeling Teamwork) Program. The program provides curriculum and training for college students to teach high school students about teamwork and the Social Change Model, focusing on bringing about positive community change through Collaboration, Controversy with Civility, Commitment, and Common Purpose.

- Polk County schools and USF Polytechnic successfully submitted a grant proposal to NASA for the Central Florida Aerospace Curriculum project to develop high-interest, NASA-oriented, high school curriculum. Central Florida Aerospace Curriculum will concurrently prepare middle school students to seek increased rigor in STEM studies and inspire participation among populations typically underrepresented in advanced courses. The curriculum will feature NASA standards for aeronautics education, for activities and experiences, and for assessment metrics. 
Additional Information on Quality, Resources, Efficiencies, and Effectiveness (continued)

\section{Challenges and Opportunities}

- USF Polytechnic's vision as a destination campus, included in the 2007-2012 Strategic Plan, will require a carefully planned and phased in approach to the development of on-campus residence halls and appropriate amenities needed to provide for residential students' physical, social, intellectual and community engagement opportunities.

- As budget becomes available, as facilities are constructed, and following all requirements of SACS accreditation, USF Polytechnic will continue to develop 2012 and beyond a faculty and staff hiring plan to enable delivery of FTIC, new degree programs, research and community engagement initiatives to transition strategically over time to the polytechnic model.

- A strategy for the development of the General Education core is expected to focus on a narrow number of course offerings, aligned with the USF Polytechnic Core Values as identified in the 20072012 Strategic Plan. This will enable USFP to deliver general education that meets State requirements, demonstrates measurable performance-based competencies, and includes fieldbased and internship experiences for all students with fewer course offerings.

- A concurrent strategy for faculty hiring is expected to focus on addition of faculty in English, mathematics and statistics, natural sciences, life sciences, humanities, political science and international affairs. Staff hiring will continue to target support for Student Affairs and academic program support. When USF Polytechnic prepares for the occupancy of the first facility on the new campus site, staff hiring will also target campus operations, maintenance, safety and security.

\section{Additional Resources}

[For example, university links should be included for the following]

\section{- Common Data Set}

- Beginning Fall 2009 USF Polytechnic began submitting institutional data to IPEDS (i.e., Institutional Characteristics, Enrollment and Completions). As additional IPEDS surveys are published over the 2009-2010 academic year, a common data set will be developed and available on the campus website. The USF Common Data Set (with aggregated data from USF Polytechnic can be found at: http://usfweb2.usf.edu/InfoMart/cds/cds2008_2009.pdf

\section{- College Navigator}

- The NCES College Navigator will populate USF Polytechnic data following all scheduled surveys submissions by our institution. According to the IPEDS Help Desk, our institutional data will be published on the College Navigator in summer 2010.

\section{- University Institutional Research Unit}

- Beginning in fall 2007, IREP has produced a fall profile which provides summary data on USF Polytechnic's students, faculty, staff, degrees and enrollment. This document can be found at: http:// poly.usf.edu/documents/IREP/2009Fall-USFPProfile.pdf 


\section{Section 9 of Annual Report: Progress on Other Primary Institutional Goals and Metrics as Outlined in the University Work Plan}

Goal 1: Recruit, develop, and retain world-class practitioner scholars with capacity to deliver the polytechnic vision in teaching, research, and community engagement.

- A comprehensive faculty recruitment plan has been developed; 31 new faculty positions are targeted for 2009-2010 recruitment for the 2010-2011 academic year. Emphasis is on practitioner-scholars with experience in polytechnic institutions and capacity to deliver the polytechnic vision in teaching, research, and community engagement and impact.

- Three interdisciplinary colleges have been established. Positions for two deans and a director have been targeted for 2009-2010

recruitment for the 2010-2011 academic year. Emphasis is on who have academic degrees from polytechnic or polytechnic-like universities and/or faculty and leadership experience in polytechnic or polytechnic-like universities.

- A faculty culture that values applied learning, applied research, interdisciplinary thinking, and integration of innovative technology is emerging.

- Clear, well-articulated criteria for promotion and tenure that reflect the nature of faculty work on a polytechnic, undergraduate and master's level campus have been developed.

Goal 2: Recruit students locally, nationally, and internationally who are prepared for a polytechnic learning environment, and provide programs and opportunities that enhance student retention and academic, personal, and professional success.

- A staff recruitment plan has been developed to support the areas of Student Affairs and Learning Labs.

- A comprehensive student recruitment plan is being developed to include regional, state, national and international markets.

- A comprehensive enrollment management plan has been developed for marketing, recruitment, admissions, advising, retention and graduation of diverse and high quality students.

- Comprehensive student life activities have been increased.
Goal 3: Expand and create academic programs that focus on applied learning, applied research, applied technology, and interdisciplinary approaches in a polytechnic model. Develop and implement new degree programs in five areas of distinction: applied health sciences; mathematics and science education; business and entrepreneurship; manufacturing engineering and technology; and information technology.

- We have selected three developmental peers: Arizona State University's Polytechnic Campus in Mesa, AZ; California Polytechnic State University in San Luis Obispo, CA; and the University of Wisconsin Stout Campus in Menomonie, WI. We have also selected two aspirational peers: Rensselaer Polytechnic Institute and Virginia Polytechnic \& State University (Virginia Tech).

- The interdisciplinary structure of USF Polytechnic's colleges will accommodate its existing degree programs, allow for the development of new degrees and reflect commitment to interdisciplinary engagement. Three colleges have been established: Technology and Innovation (housing academic divisions of Innovation Management, Engineering and Applied Sciences, and Information Technology); Human and Social Sciences (housing academic divisions of Education, Social Sciences and Allied Health Sciences); and Applied Arts and New Media (housing academic divisions of Architecture and Design, Technical and Professional Communication, and Digital Arts and Digital Media).

- The Initial SACS Accreditation Application is targeted for submission in February 2010.

- The completion of the SRI International cluster study provided needs assessment for potential long-term regional workforce and economic development.

- A new campus website was launched with a site architecture designed for student-centered interest and access and clarity of information. 
Section 9 of Annual Report: Progress on Other Primary Institutional Goals and Metrics as Outlined in the University Work Plan (Continued)

Goal 4: Implement the Campus Master Plan and develop a campus infrastructure to support a polytechnic learning and research environment, and develop a stable economic base for continued campus and program development as a polytechnic campus.

- Completed a Master Plan with update presentated to the USF Board of Trustees in October 2009.

- Selected an internationally acclaimed architect.

- Selected a location for the first facility.

The Architect/Engineer RFP included the opportunity to update the existing Master Plan which was developed in 2005-06 and approved by the USF Board of Trustees in 2007. As a result of the RFP process, the campus engaged a world-class architect, Dr. Santiago Calatrava who is a product of several polytechnic universities in Europe. The Master Plan update, scheduled for completion in October 2009, allows for the exposure of the first facility to the millions of annual travelers along Interstate 4 (movement of the location of that facility was approved by the Academic and Campus Environment Workgroup on May 28, 2009, and the full Board of Trustees on June 25, 2009). The first facility will establish an open, multipurpose design in support of the interdisciplinary and collaborative learning environment foundational to a polytechnic experience for our students. It will also focus on sustainability and synergy with the natural environment. This update will be incorporated into the University's 2010 Master Plan update currently being developed.

The site for the campus is currently a green field site with no existing amenities including access to the site and infrastructure (including internal roads, water, electricity, sewers, waste removal, etc.).

Construction for infrastructure will begin in spring 2010 while Phase I facilities are in design. Construction of Phase I facilities will begin in fall 2010 with a 20-month construction period anticipated, projecting occupancy in summer 2012.
Goal 5: Develop collaborative public and private partnerships that enhance funding opportunities, including leveraging state and federal funding.

- Extended University established to increase community education opportunities to support lifelong learning.

- Increased visibility achieved through an image and marketing plan communicating the polytechnic model, vision and mission.

- Polk County Investment \$11.7 million. Polk County officials identified the need to reach the site from the East, seeing value in combining efforts with the University by creating synergistic sports opportunities in the county's Lake Myrtle complex and linking them to the campus site (less than 2 miles away). To that end Polk County designed and constructed a four-lane access from Berkeley Road to the Polk Parkway, creating a major entrance gateway to the campus from the east.

- State of Florida Turnpike Authority Investment \$31.9 million; Williams Company \$9.4 million. The Turnpike Authority recognized the need for access to the campus and its surrounding developments via the Polk Parkway. Numerous discussions have taken place over several years resulting in a pledge to create a $\$ 32$ million exit interchange at Pace Road from the Polk Parkway. This commitment, along with a project to four-lane the Polk Parkway from Interstate 4 to the Pace Road interchange, resulted in a partnership that included a pledge from the Williams Company toward the project. The RFP for this project has been concluded and the design-build contract is currently under negotiation. Groundbreaking is being planned for January 2010, and the project is scheduled to be completed prior to the anticipated opening of the new campus in fall 2012.

- Florida Department of Transportation Investment \$28 million. While the Pace Road and Turnpike projects yielded access to the site from the east, the more pressing concerns from the local host community revolved around access to the property from the west for life-safety responses as well as for access for the largest concentration of constituents for the campus. The Florida Department of Transportation, in concert with the City of Lakeland and the Transportation Planning Council of Polk County, identified the East/West Road project (a 6-mile long road connecting State Road 33 from the west with Pace Road on the east) as their Number 1 priority 
Section 9 of Annual Report: Progress on Other Primary Institutional Goals and Metrics as Outlined in the University Work Plan

\section{(Continued)}

for this year. An RFP developed by the FDOT is currently in play, with expected finalization of a contract and initiation of construction as early as March 2010 and anticipated completion no later than

March 2012.

- Estimated Needed Investment \$10 million (In development process). The university is currently pursuing funding strategies with local investors and seeking potential FEGC matching funds for the campus facilities' infrastructure.

- PECO State Funds $\$ 31.2$ million (received) and additional \$10

million anticipated in 2010; CITF funds of \$390,000; Investments from Private Sources $\$ 10.7$ million with anticipated FEGC match. These funds will build the first facility on the campus (Phase I), the Science $\&$ Technology Building. The estimated total cost of the first facility is $\$ 62$ million.

- PECO request \$5 million (on current CIP listing); Private Investment $\$ 5$ million (pledged over 3 years, first year received) eligible for FECG match. These funds will build the Interdisciplinary Center for

Wellness Education and Research, a multi-purpose facility exemplifying the ideal blend of Town and Gown, bringing the general public and the campus community together around wellness issues, education and research.

- Private Investment $\$ 1$ million (received). The interdisciplinary, applied learning and research in a polytechnic environment, brings the prospect of engaging creative, entrepreneurial energies in the evolving high technology arena of Central Florida as well as engaging polytechnic students in related educational experiences (e.g., learning lab practica and internships). The campus Master Plan included the development of a High Tech incubator, and the updated Master Plan includes the development of an applied learning laboratory where students and aspiring entrepreneurs will work together in the development of new ideas and application of established and emerging research to bring about innovation. 


\section{Appendices}

\section{List of Tables}

1 - Budget

2 - Federal Stimulus Dollars (ARRA)

3 - Other Core Resources

4 - Enrollment and Funding

5 - Undergraduate Education Data

A. Baccalaureate Degree Programs Implemented or Terminated

B. First-Year Persistence Rates

C. Undergraduate Progression and Graduation Rates

D. Baccalaureate Degrees Awarded

E. Baccalaureate Degrees Awarded in Areas of Strategic Emphasis

F. Baccalaureate Degrees Awarded to Underrepresented Groups

G. Baccalaureate Completions Without Excess Credit Hours

H. Undergraduate Course Offerings

I. Faculty Teaching Undergraduates

J. Undergraduate Instructional Faculty Compensation

K. Student-Faculty Ratios

L. Licensure Examination Pass Rates (Undergraduate)

M. Tuition Differential

6 - Graduate Education Data

A. Graduate Degree Programs Implemented or Terminated

B. Graduate Degrees Awarded

C. Graduate Degrees Awarded in Areas of Strategic Emphasis

D. Licensure Examination Pass Rates (Graduate)

7 - Research and Economic Development Data

A. Research and Development Expenditures

B. Other Research and Economic Development Outcomes

C. Centers of Excellence

D. Commercialization Assistance Grants

8 - Voluntary Support of Higher Education

9 - Progress on Other Primary Institutional Goals and Metrics As Outlined in the University Work Plan 


\begin{tabular}{|c|c|c|c|c|c|}
\hline \multicolumn{6}{|c|}{1 - Budget (Non-Medical) } \\
\hline & 2005-06 Actual & 2006-07 Actual & 2007-08 Actual & 2008-09 Actual & $\begin{array}{c}2009-10 \\
\text { Estimates }\end{array}$ \\
\hline \multicolumn{6}{|l|}{ Education and General } \\
\hline \multicolumn{6}{|l|}{ E\&G Revenues } \\
\hline $\begin{array}{c}\text { State Funds (Recurring GR } \\
\text { \& Lottery) }\end{array}$ & $\$ 10,721,790$ & $\$ 11,561,495$ & $\$ 10,053,299$ & $\$ 9,394,081$ & $\$ 13,016,780$ \\
\hline $\begin{array}{c}\text { State Funds (Non- } \\
\text { Recurring GR \& Lottery) }\end{array}$ & $\$ 0$ & $\$ 53,000$ & $\$ 102,875$ & $\$ 98,300$ & $\$ 59,794$ \\
\hline $\begin{array}{c}\text { Tuition (Resident/Non- } \\
\text { Resident) }\end{array}$ & $\$ 2,224,848$ & $\$ 2,249,992$ & $\$ 2,743,529$ & $\$ 3,787,462$ & $\$ 5,031,679$ \\
\hline Tuition Differential (UG) & $\$ 0$ & $\$ 0$ & $\$ 0$ & $\$ 0$ & $\$ 132,477$ \\
\hline $\begin{array}{l}\text { Other (Include Revenues } \\
\text { from Misc. Fees \& Fines) }\end{array}$ & $\$ 66,122$ & $\$ 74,724$ & $\$ 3,109$ & $\$ 2,332$ & $\$ 4,845$ \\
\hline $\begin{array}{c}\text { Phosphate Research Trust } \\
\text { Fund }\end{array}$ & $\$ 0$ & $\$ 0$ & $\$ 0$ & $\$ 0$ & $\$ 0$ \\
\hline Federal Stimulus Funds & $\$ 0$ & $\$ 0$ & $\$ 0$ & $\$ 0$ & $\$ 708,656$ \\
\hline \multirow[t]{2}{*}{ TOTAL } & $\$ 13,012,760$ & $\$ 13,939,211$ & $\$ 12,902,812$ & $\$ 13,282,175$ & $\$ 18,954,231$ \\
\hline & 2005-06 Actual & 2006-07 Actual & 2007-08 Actual & 2008-09 Actual & $\begin{array}{c}2009-10 \\
\text { Estimates }\end{array}$ \\
\hline \multicolumn{6}{|l|}{ EEG Expenditures } \\
\hline Instruction/Research & $\$ 8,649,720$ & $\$ 8,859,479$ & $\$ 9,420,645$ & $\$ 7,041,399$ & $\$ 10,757,549$ \\
\hline $\begin{array}{c}\text { Institutes and Research } \\
\text { Centers } \\
\end{array}$ & $\$ 0$ & $\$ 0$ & $\$ 0$ & $\$ 0$ & $\$ 0$ \\
\hline PO\&M & $\$ 232,525$ & $\$ 302,130$ & $\$ 187,904$ & $\$ 156,064$ & $\$ 76,347$ \\
\hline $\begin{array}{c}\text { Administration and } \\
\text { Support Services } \\
\end{array}$ & $\$ 917,123$ & $\$ 1,289,783$ & $\$ 1,444,066$ & $\$ 2,309,412$ & $\$ 7,053,836$ \\
\hline Radio/TV & $\$ 0$ & $\$ 0$ & $\$ 0$ & $\$ 0$ & $\$ 0$ \\
\hline Library/Audio Visual & $\$ 166,327$ & $\$ 209,905$ & $\$ 237,544$ & $\$ 415,527$ & $\$ 423,558$ \\
\hline Museums and Galleries & $\$ 0$ & $\$ 0$ & $\$ 0$ & $\$ 0$ & $\$ 0$ \\
\hline Agricultural Extension & $\$ 0$ & $\$ 0$ & $\$ 0$ & $\$ 0$ & $\$ 0$ \\
\hline Allied Clinics & $\$ 0$ & $\$ 0$ & $\$ 0$ & $\$ 0$ & $\$ 0$ \\
\hline Student Services & $\$ 573,940$ & $\$ 697,090$ & $\$ 779,724$ & $\$ 755,885$ & $\$ 642,941$ \\
\hline Intercollegiate Athletics & $\$ 0$ & $\$ 0$ & $\$ 0$ & $\$ 0$ & $\$ 0$ \\
\hline TOTAL & $\$ 10,539,634$ & $\$ 11,358,387$ & $\$ 12,069,883$ & $\$ 10,678,287$ & $\$ 18,954,231$ \\
\hline
\end{tabular}




\begin{tabular}{|c|c|c|c|c|c|}
\hline & 05-06 Actual & 06-07 Actual & 07-08 Actual & 08-09 Actual & $\begin{array}{c}2009-10 \\
\text { Estimates }\end{array}$ \\
\hline \multicolumn{6}{|l|}{ Contracts and Grants } \\
\hline Revenues & \multirow{2}{*}{\multicolumn{5}{|c|}{$\begin{array}{l}\text { Contracts \& Grants data is a USF system-wide function and consolidated system } \\
\text { data is only available at this time. }\end{array}$}} \\
\hline Expenditures & & & & & \\
\hline \multicolumn{6}{|l|}{ Auxiliary Enterprises } \\
\hline Revenues & \multirow{2}{*}{\multicolumn{5}{|c|}{$\begin{array}{l}\text { Auxiliary Enterprise data is a USF system-wide function and consolidated system } \\
\text { data is only available at this time. }\end{array}$}} \\
\hline Expenditures & & & & & \\
\hline \multicolumn{6}{|l|}{ Local Funds } \\
\hline Revenues & \multirow{2}{*}{\multicolumn{5}{|c|}{$\begin{array}{l}\text { Local Funds data is a USF system-wide function and consolidated system data is } \\
\text { only available at this time. }\end{array}$}} \\
\hline Expenditures & & & & & \\
\hline TOTAL REVENUES & $\$ 13,012,760$ & $\$ 13,939,211$ & $\$ 12,902,812$ & $\$ 13,282,175$ & $\$ 18,954,231$ \\
\hline TOTAL EXPENDITURES & $\$ 10,539,634$ & $\$ 11,358,387$ & $\$ 12,069,883$ & $\$ 10,678,287$ & $\$ 18,954,231$ \\
\hline \multicolumn{6}{|c|}{2 - Federal Stimulus Dollars (ARRA) } \\
\hline & & & & \multicolumn{2}{|c|}{ Proposed 2009-10 } \\
\hline & & & & \multicolumn{2}{|c|}{ USF (No HSC) } \\
\hline \# Jobs Saved/Created & & & & \multicolumn{2}{|c|}{22.6} \\
\hline \multicolumn{6}{|c|}{ Proposed Operating Budget Detail } \\
\hline \multicolumn{4}{|l|}{ Jobs Saved/Created } & \multicolumn{2}{|c|}{$\$ 708,656$} \\
\hline \multicolumn{4}{|l|}{ Scholarships } & \multicolumn{2}{|c|}{10} \\
\hline \multicolumn{4}{|l|}{ Library Resources } & \multicolumn{2}{|c|}{0} \\
\hline \multicolumn{4}{|c|}{ Building Repairs/Alterations } & \multicolumn{2}{|c|}{0} \\
\hline \multicolumn{4}{|c|}{ Motor Vehicles } & \multicolumn{2}{|c|}{0} \\
\hline \multicolumn{4}{|l|}{ Printing } & \multicolumn{2}{|c|}{0} \\
\hline \multicolumn{4}{|c|}{ Furniture \& Equipment } & \multicolumn{2}{|c|}{0} \\
\hline \multicolumn{4}{|c|}{ Information Technology Equipment } & \multicolumn{2}{|c|}{0} \\
\hline \multicolumn{4}{|c|}{ Financial Aid to Medical Students } & \multicolumn{2}{|c|}{0} \\
\hline \multicolumn{4}{|c|}{ Other: } & \multicolumn{2}{|c|}{0} \\
\hline \multicolumn{4}{|l|}{ TOTAL } & $\$ 70$ & 666 \\
\hline
\end{tabular}




\begin{tabular}{|c|c|c|c|c|c|}
\hline \multicolumn{6}{|c|}{1 - Budget (Special Units-Health Science Center) } \\
\hline & 2005-06 Actual & 2006-07 Actual & 2007-08 Actual & 2008-09 Actual & $\begin{array}{c}2009-10 \\
\text { Estimates }\end{array}$ \\
\hline Health Science Center & & & & & \\
\hline HSC Revenues & & & & & \\
\hline $\begin{array}{c}\text { State Funds (Recurring GR } \\
\text { \& Lottery) }\end{array}$ & \multirow{8}{*}{\multicolumn{5}{|c|}{ DATA ARE ONLY APPLICABLE TO USF TAMPA }} \\
\hline $\begin{array}{c}\text { State Funds (Non- } \\
\text { Recurring GR \& Lottery) }\end{array}$ & & & & & \\
\hline $\begin{array}{c}\text { Tuition (Resident/Non- } \\
\text { Resident) }\end{array}$ & & & & & \\
\hline Tuition Differential (UG) & & & & & \\
\hline $\begin{array}{l}\text { Other (Include Revenues } \\
\text { from Misc. Fees \& Fines) }\end{array}$ & & & & & \\
\hline $\begin{array}{c}\text { Phosphate Research Trust } \\
\text { Fund } \\
\end{array}$ & & & & & \\
\hline Federal Stimulus Funds & & & & & \\
\hline TOTAL & & & & & \\
\hline & 2005-06 Actual & 2006-07 Actual & 2007-08 Actual & 2008-09 Actual & $\begin{array}{c}\text { 2009-10 } \\
\text { Estimates }\end{array}$ \\
\hline HSC Expenditures & & & & & 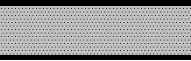 \\
\hline Instruction/Research & \multirow{12}{*}{\multicolumn{5}{|c|}{ DATA ARE ONLY APPLICABLE TO USF TAMPA }} \\
\hline $\begin{array}{c}\text { Institutes and Research } \\
\text { Centers } \\
\end{array}$ & & & & & \\
\hline PO\&M & & & & & \\
\hline $\begin{array}{l}\text { Administration and } \\
\text { Support Services }\end{array}$ & & & & & \\
\hline Radio/TV & & & & & \\
\hline Library/Audio Visual & & & & & \\
\hline Museums and Galleries & & & & & \\
\hline Agricultural Extension & & & & & \\
\hline Allied Clinics & & & & & \\
\hline Student Services & & & & & \\
\hline Intercollegiate Athletics & & & & & \\
\hline TOTAL & & & & & \\
\hline
\end{tabular}




\begin{tabular}{|l|c|}
\hline \multicolumn{2}{|c|}{ 2 - Federal Stimulus Dollars (ARRA) } \\
\hline & Proposed 2009-10 \\
\hline \# Jobs Saved/Created & $\mathrm{N} / \mathrm{A}$ \\
\hline Proposed Operating Budget Detail & $\mathrm{N} / \mathrm{A}$ \\
\hline Jobs Saved/Created & $\mathrm{N} / \mathrm{A}$ \\
\hline Scholarships & $\mathrm{N} / \mathrm{A}$ \\
\hline Library Resources & $\mathrm{N} / \mathrm{A}$ \\
\hline Building Repairs/Alterations & $\mathrm{N} / \mathrm{A}$ \\
\hline Motor Vehicles & $\mathrm{N} / \mathrm{A}$ \\
\hline Printing & $\mathrm{N} / \mathrm{A}$ \\
\hline Furniture \& Equipment & $\mathrm{N} / \mathrm{A}$ \\
\hline Information Technology Equipment & $\mathrm{N} / \mathrm{A}$ \\
\hline Financial Aid to Medical Students & $\mathrm{N} / \mathrm{A}$ \\
\hline Other: & $\mathrm{N} / \mathrm{A}$ \\
\hline TOTAL & \\
\hline
\end{tabular}




\begin{tabular}{|c|c|c|c|c|c|}
\hline \multicolumn{2}{|c|}{3 - Other Core Resources } \\
\hline $\begin{array}{c}\text { Funding per Student FTE } \\
\text { (US Definition) }\end{array}$ & $2005-06$ & $2006-07$ & $2007-08$ & $2008-09$ & $2009-10$ \\
\hline General Revenue per FTE & $\$ 12,420$ & $\$ 13,921$ & $\$ 10,554$ & $\$ 7,530$ & $\$ 10,156$ \\
\hline Lottery Funds per FTE & $\$ 482$ & $\$ 561$ & $\$ 36$ & $\$ 276$ & $\$ 182$ \\
\hline Other Trust Funds per FTE & $\$ 0$ & $\$ 0$ & $\$ 0$ & $\$ 0$ & $\$ 560$ \\
\hline Student Fees per FTE & $\$ 2,757$ & $\$ 2,899$ & $\$ 13,864$ & $\$ 17,454$ & $\$ 10,923$ \\
\hline Total per FTE Student & $\$ 15,659$ & $\$ 17,381$ & $\$ 14,984$ \\
\hline
\end{tabular}

** FTE for this metric uses the standard IPEDS definition of FTE, equal to 30 credit hours for undergraduates and 24 for graduates.

\begin{tabular}{|c|c|c|c|c|c|c|c|c|c|c|}
\hline \multirow{2}{*}{ Personnel Headcount } & \multicolumn{2}{|c|}{ Fall 2004} & \multicolumn{2}{|c|}{ Fall 2005} & \multicolumn{2}{|c|}{ Fall 2006} & \multicolumn{2}{|c|}{ Fall 2007} & \multicolumn{2}{|c|}{ Fall 2008} \\
\hline & FT & PT & FT & PT & FT & PT & FT & PT & FT & PT \\
\hline $\begin{array}{l}\text { Total Tenure/ Tenure-track } \\
\text { Faculty }\end{array}$ & 15 & 2 & 22 & 0 & 22 & 0 & 23 & 0 & 19 & 0 \\
\hline $\begin{array}{c}\text { Total Non-Tenure Track } \\
\text { Faculty }\end{array}$ & 8 & 6 & 10 & 3 & 13 & 3 & 14 & 2 & 12 & 6 \\
\hline $\begin{array}{l}\text { Total Graduate Assistants/ } \\
\text { Associates }\end{array}$ & & 12 & & 7 & & 5 & & 4 & & 2 \\
\hline $\begin{array}{l}\text { Total Executive/ Ad- } \\
\text { ministrative/ Managerial }\end{array}$ & 13 & 0 & 16 & 0 & 17 & 0 & 22 & 0 & 18 & 0 \\
\hline Total Other Professional & 23 & 0 & 25 & 0 & 24 & 1 & 25 & 0 & 18 & 0 \\
\hline Total Non-Professional & 17 & 0 & 18 & 0 & 15 & 0 & 20 & 0 & 21 & \\
\hline Space & \multicolumn{2}{|c|}{ Fall 2004} & \multicolumn{2}{|c|}{ Fall 2005} & \multicolumn{2}{|c|}{ Fall 2006} & \multicolumn{2}{|c|}{ Fall 2007} & \multicolumn{2}{|c|}{ Fall 2008} \\
\hline $\begin{array}{l}\text { Space Utilization } \\
\text { Percentage (Classrooms) }\end{array}$ & \multicolumn{10}{|c|}{ UTILIZATION IS ONLY CALCULATED FOR OWNED FACILITIES } \\
\hline
\end{tabular}




\begin{tabular}{|c|c|c|c|c|c|c|}
\hline \multicolumn{7}{|c|}{4 - Enrollment and Funding } \\
\hline $\begin{array}{l}\text { For entire } \\
\text { institution: } \\
\text { Annual FTE }\end{array}$ & $\begin{array}{l}\text { Funded } \\
2007-08\end{array}$ & $\begin{array}{r}2007-08 \\
\text { Actual }\end{array}$ & $\begin{array}{l}\text { Funded } \\
2008-09\end{array}$ & 2008-09 Actual & $\begin{array}{l}\text { Funded } \\
2009-10\end{array}$ & $\begin{array}{c}2009-10 \\
\text { Estimated }\end{array}$ \\
\hline $\begin{array}{c}\text { FL Resident } \\
\text { Lower }\end{array}$ & 0 & 11 & 0 & 22 & 0 & 31 \\
\hline $\begin{array}{c}\text { FL Resident } \\
\text { Upper }\end{array}$ & 494 & 588 & 494 & 748 & 494 & 786 \\
\hline $\begin{array}{c}\text { FL Resident } \\
\text { Grad I }\end{array}$ & 103 & 110 & 103 & 132 & 103 & 122 \\
\hline $\begin{array}{c}\text { FL Resident } \\
\text { Grad II }\end{array}$ & 0 & 0 & 0 & 1 & 0 & 0 \\
\hline $\begin{array}{c}\text { Total FL } \\
\text { Resident } \\
\end{array}$ & 597 & 709 & 597 & 902 & 597 & 939 \\
\hline $\begin{array}{l}\text { Non-Res. } \\
\text { Lower }\end{array}$ & & 0 & & 0 & & 0 \\
\hline $\begin{array}{l}\text { Non-Res. } \\
\text { Upper }\end{array}$ & & 8 & & 9 & & 9 \\
\hline $\begin{array}{c}\text { Non-Res. Grad } \\
\text { I } \\
\end{array}$ & & 1 & & 1 & & 1 \\
\hline $\begin{array}{c}\text { Non-Res. Grad } \\
\text { II } \\
\end{array}$ & & 0 & & 0 & & 0 \\
\hline Total Non-Res. & 9 & 9 & 9 & 11 & 9 & 10 \\
\hline Total Lower & & 11 & & 22 & & 31 \\
\hline Total Upper & & 596 & & 757 & & 795 \\
\hline Total Grad I & & 111 & & 133 & & 123 \\
\hline Total Grad II & & 1 & & 1 & & 0 \\
\hline Total FTE & 606 & 719 & 606 & 913 & 606 & 949 \\
\hline $\begin{array}{c}\text { Total FTE - US } \\
\text { Definition* }\end{array}$ & 822 & 959 & 822 & 1,217 & 822 & 1,265 \\
\hline
\end{tabular}




\begin{tabular}{|c|c|c|c|c|c|c|}
\hline Annual FTE & $\begin{array}{l}\text { Funded } \\
2007-08 \\
\end{array}$ & $\begin{array}{l}2007-08 \\
\text { Actual } \\
\end{array}$ & $\begin{array}{l}\text { Funded } \\
2008-09\end{array}$ & $\begin{array}{l}2008-09 \\
\text { Actual } \\
\end{array}$ & $\begin{array}{l}\text { Funded } \\
2009-10 \\
\end{array}$ & $\begin{array}{c}2009-10 \\
\text { Estimated }\end{array}$ \\
\hline $\begin{array}{c}\text { FL Resident } \\
\text { Medical } \\
\text { Headcount } \\
\end{array}$ & 0 & 0 & 0 & 0 & 0 & 0 \\
\hline $\begin{array}{c}\text { Non-Res. } \\
\text { Medical } \\
\text { Headcount } \\
\end{array}$ & & 0 & & 0 & & 0 \\
\hline $\begin{array}{c}\text { Total Medical } \\
\text { Headcount }\end{array}$ & & 0 & & 0 & & 0 \\
\hline $\begin{array}{l}\text { FL Resident } \\
\text { Dentistry } \\
\text { Headcount }\end{array}$ & 0 & 0 & 0 & 0 & 0 & 0 \\
\hline $\begin{array}{c}\text { Non-Res. } \\
\text { Dentistry } \\
\text { Headcount } \\
\end{array}$ & & 0 & & 0 & & 0 \\
\hline $\begin{array}{c}\text { Total Dentistry } \\
\text { Headcount }\end{array}$ & & 0 & & 0 & & 0 \\
\hline $\begin{array}{l}\text { FL Resident } \\
\text { Veterinary } \\
\text { Medicine } \\
\text { Headcount }\end{array}$ & 0 & 0 & 0 & 0 & 0 & 0 \\
\hline $\begin{array}{c}\text { Non-Res. } \\
\text { Veterinary } \\
\text { Medicine } \\
\text { Headcount }\end{array}$ & & 0 & & 0 & & 0 \\
\hline $\begin{array}{c}\text { Total } \\
\text { Veterinary } \\
\text { Medicine } \\
\text { Headcount } \\
\end{array}$ & & 0 & & 0 & & 0 \\
\hline $\begin{array}{l}\text { Total Non-Res. } \\
\text { Med., Den., } \\
\text { Vet. Medicine } \\
\text { Headcount }\end{array}$ & 0 & 0 & 0 & 0 & 0 & 0 \\
\hline
\end{tabular}




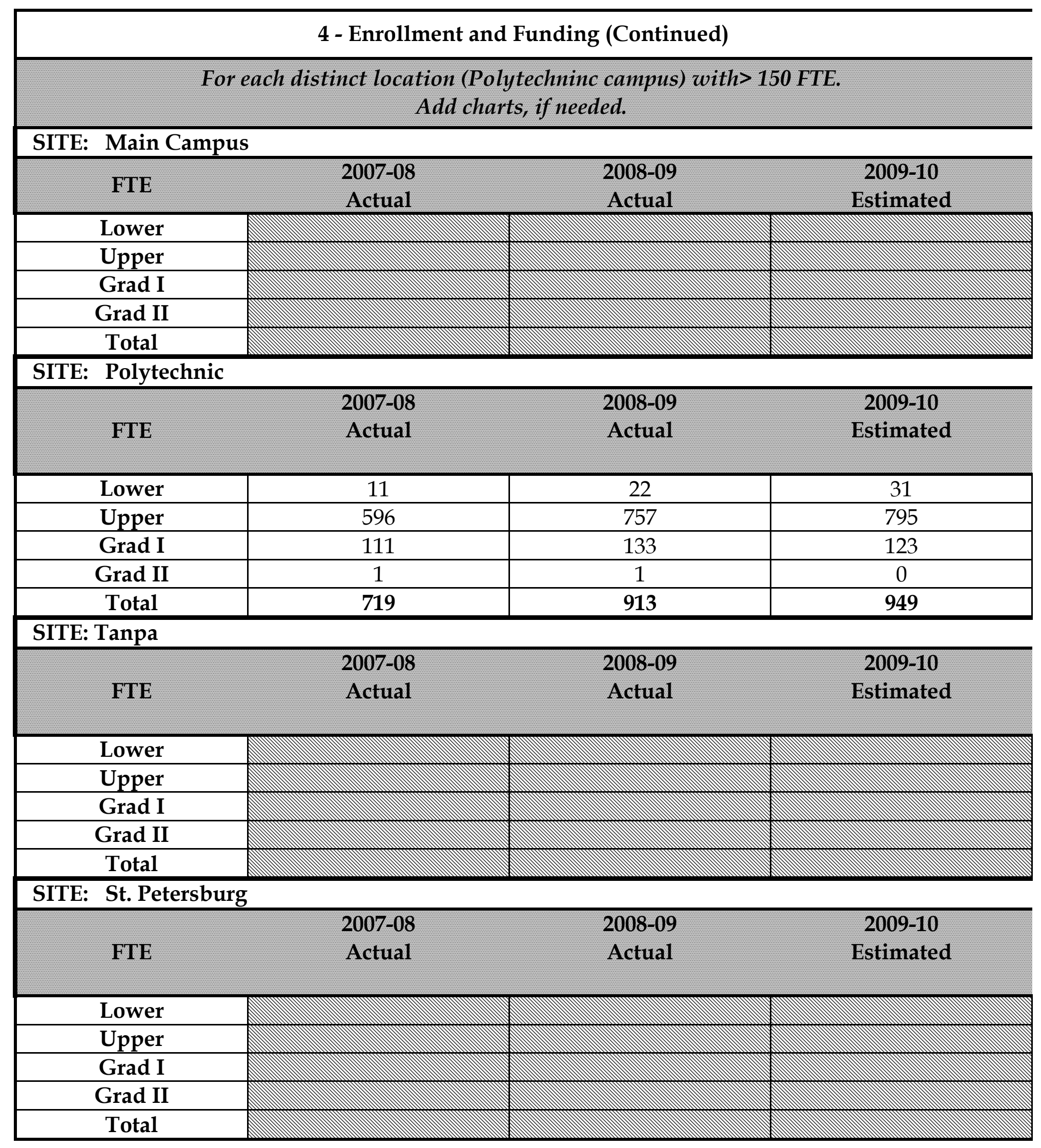


4 - Enrollment and Funding (Continued)

\section{SITE: USF Medical Center/Main Campus}

(1)




\begin{tabular}{|c|c|c|c|c|c|}
\hline \multicolumn{6}{|c|}{5 - Undergraduate Education Data } \\
\hline $\begin{array}{l}\text { 5A. Baccalaureate } \\
\text { Degree Programs } \\
\text { Implemented or } \\
\text { Terminated } \\
\end{array}$ & \multirow{2}{*}{$\begin{array}{l}\text { New } \\
\text { Program or } \\
\text { Termina- } \\
\text { tion? }\end{array}$} & \multirow[t]{2}{*}{$\begin{array}{l}\text { Date } \\
\text { Approved } \\
\text { by UBOT }\end{array}$} & \multirow{2}{*}{$\begin{array}{c}\text { Date } \\
\text { Approved } \\
\text { by BOG, if } \\
\text { Needed }\end{array}$} & \multirow[t]{2}{*}{$\begin{array}{c}\text { Implementa- } \\
\text { tion Date, if } \\
\text { New }\end{array}$} & \multirow[t]{2}{*}{$\begin{array}{l}\text { Program } \\
\text { CIP Code }\end{array}$} \\
\hline $\begin{array}{c}\text { Title and Program } \\
\text { Level }\end{array}$ & & & & & \\
\hline General Studies & New & $6 / 12 / 2008$ & $\mathrm{n} / \mathrm{a}$ & Fall 2008 & 24.0102 \\
\hline General Studies & New & $6 / 12 / 2008$ & $\mathrm{n} / \mathrm{a}$ & Fall 2008 & 24.0102 \\
\hline & \multicolumn{4}{|c|}{ 5B. Successful First-Year Persistence Rates } & \\
\hline $\begin{array}{c}\text { YEAR OF SUS } \\
\text { MATRICULATION }\end{array}$ & 2003 & 2004 & 2005 & 2006 & 2007 \\
\hline $\begin{array}{c}\text { Full-Time FTIC } \\
\text { Cohort (Fall/Summer- } \\
\text { Fall) Size }\end{array}$ & 0 & 0 & 0 & 0 & 0 \\
\hline $\begin{array}{c}\text { Percentage Enrolled in } \\
\text { Same IHE After One } \\
\text { Year }\end{array}$ & N/A & N/A & N/A & $\mathrm{N} / \mathrm{A}$ & $\mathrm{N} / \mathrm{A}$ \\
\hline
\end{tabular}




\begin{tabular}{|c|c|c|c|c|c|}
\hline \multicolumn{6}{|c|}{ 5C. Successful Undergraduate Progression and Graduation Rates } \\
\hline $\begin{array}{c}\text { YEAR OF SUS } \\
\text { MATRICULATION }\end{array}$ & 1999 & 2000 & 2001 & 2002 & 2003 \\
\hline $\begin{array}{c}\text { FTIC Cohort } \\
\text { (Fall/Summer-Fall) } \\
\text { Size }\end{array}$ & 0 & 0 & 0 & 0 & 0 \\
\hline $\begin{array}{c}\text { Percentage Graduated } \\
\text { from Same IHE } \\
\text { Within } 4 \text { Years }\end{array}$ & $\mathrm{N} / \mathrm{A}$ & $\mathrm{N} / \mathrm{A}$ & $\mathrm{N} / \mathrm{A}$ & $\mathrm{N} / \mathrm{A}$ & $\mathrm{N} / \mathrm{A}$ \\
\hline $\begin{array}{c}\text { Percentage Graduated } \\
\text { from Other SUS IHE } \\
\text { Within } 4 \text { Years }\end{array}$ & $\mathrm{N} / \mathrm{A}$ & N/A & $\mathrm{N} / \mathrm{A}$ & $\mathrm{N} / \mathrm{A}$ & $\mathrm{N} / \mathrm{A}$ \\
\hline $\begin{array}{c}\text { Percentage Enrolled in } \\
\text { Same IHE After } 4 \\
\text { Years } \\
\end{array}$ & N/A & $\mathrm{N} / \mathrm{A}$ & $\mathrm{N} / \mathrm{A}$ & $\mathrm{N} / \mathrm{A}$ & $\mathrm{N} / \mathrm{A}$ \\
\hline $\begin{array}{c}\text { Percentage Enrolled in } \\
\text { Other SUS IHE After } \\
4 \text { Years } \\
\end{array}$ & N/A & N/A & $\mathrm{N} / \mathrm{A}$ & $\mathrm{N} / \mathrm{A}$ & $\mathrm{N} / \mathrm{A}$ \\
\hline $\begin{array}{c}\text { TOTAL 4-Year } \\
\text { Success and Progress } \\
\text { Rate (Graduated or } \\
\text { Enrolled in SUS) }\end{array}$ & $\mathrm{N} / \mathrm{A}$ & N/A & N/A & N/A & $\mathrm{N} / \mathrm{A}$ \\
\hline $\begin{array}{c}\text { Percentage Graduated } \\
\text { from Same IHE } \\
\text { Within } 6 \text { Years }\end{array}$ & N/A & N/A & N/A & N/A & $\mathrm{N} / \mathrm{A}$ \\
\hline $\begin{array}{c}\text { Percentage Graduated } \\
\text { from Other SUS IHE } \\
\text { Within } 6 \text { Years }\end{array}$ & N/A & N/A & $\mathrm{N} / \mathrm{A}$ & N/A & $\mathrm{N} / \mathrm{A}$ \\
\hline $\begin{array}{c}\text { Percentage Enrolled in } \\
\text { Same IHE After } 6 \\
\text { Years }\end{array}$ & N/A & N/A & N/A & N/A & $\mathrm{N} / \mathrm{A}$ \\
\hline $\begin{array}{c}\text { Percentage Enrolled in } \\
\text { Other SUS IHE After } \\
6 \text { Years }\end{array}$ & N/A & N/A & N/A & $\mathrm{N} / \mathrm{A}$ & $\mathrm{N} / \mathrm{A}$ \\
\hline $\begin{array}{c}\text { TOTAL 6-Year } \\
\text { Success and Progress } \\
\text { Rate (Graduated or } \\
\text { Enrolled in SUS) }\end{array}$ & N/A & N/A & N/A & N/A & $\mathrm{N} / \mathrm{A}$ \\
\hline
\end{tabular}




\begin{tabular}{|c|c|c|c|c|c|}
\hline $\begin{array}{c}\text { YEAR OF SUS } \\
\text { MATRICULATION }\end{array}$ & 2001 & 2002 & 2003 & 2004 & 2005 \\
\hline $\begin{array}{l}\text { AA Transfer Cohort } \\
\text { (Fall/Summer-Fall) } \\
\text { Size }\end{array}$ & N/A & $\mathrm{N} / \mathrm{A}$ & N/A & N/A & $\mathrm{N} / \mathrm{A}$ \\
\hline $\begin{array}{c}\text { Percentage Graduated } \\
\text { from Same IHE } \\
\text { Within } 2 \text { Years }\end{array}$ & N/A & $\mathrm{N} / \mathrm{A}$ & N/A & $\mathrm{N} / \mathrm{A}$ & $\mathrm{N} / \mathrm{A}$ \\
\hline $\begin{array}{c}\text { Percentage Graduated } \\
\text { from Other SUS IHE } \\
\text { Within } 2 \text { Years }\end{array}$ & N/A & N/A & N/A & $\mathrm{N} / \mathrm{A}$ & $\mathrm{N} / \mathrm{A}$ \\
\hline $\begin{array}{c}\text { Percentage Enrolled in } \\
\text { Same IHE After } 2 \\
\text { Years } \\
\end{array}$ & N/A & N/A & $\mathrm{N} / \mathrm{A}$ & N/A & $\mathrm{N} / \mathrm{A}$ \\
\hline $\begin{array}{c}\text { Percentage Enrolled in } \\
\text { Other SUS IHE After } \\
2 \text { Years }\end{array}$ & N/A & $\mathrm{N} / \mathrm{A}$ & $\mathrm{N} / \mathrm{A}$ & $\mathrm{N} / \mathrm{A}$ & $\mathrm{N} / \mathrm{A}$ \\
\hline $\begin{array}{c}\text { TOTAL 2-Year } \\
\text { Success and Progress } \\
\text { Rate (Graduated or } \\
\text { Enrolled in SUS) }\end{array}$ & N/A & $\mathrm{N} / \mathrm{A}$ & $\mathrm{N} / \mathrm{A}$ & N/A & $\mathrm{N} / \mathrm{A}$ \\
\hline $\begin{array}{l}\text { Percentage Graduated } \\
\text { from Same IHE } \\
\text { Within } 4 \text { Years }\end{array}$ & $\mathrm{N} / \mathrm{A}$ & $\mathrm{N} / \mathrm{A}$ & $\mathrm{N} / \mathrm{A}$ & $\mathrm{N} / \mathrm{A}$ & $\mathrm{N} / \mathrm{A}$ \\
\hline $\begin{array}{c}\text { Percentage Graduated } \\
\text { from Other SUS IHE } \\
\text { Within } 4 \text { Years }\end{array}$ & $\mathrm{N} / \mathrm{A}$ & $\mathrm{N} / \mathrm{A}$ & $\mathrm{N} / \mathrm{A}$ & $\mathrm{N} / \mathrm{A}$ & $\mathrm{N} / \mathrm{A}$ \\
\hline $\begin{array}{c}\text { Percentage Enrolled in } \\
\text { Same IHE After } 4 \\
\text { Years }\end{array}$ & $\mathrm{N} / \mathrm{A}$ & $\mathrm{N} / \mathrm{A}$ & $\mathrm{N} / \mathrm{A}$ & $\mathrm{N} / \mathrm{A}$ & $\mathrm{N} / \mathrm{A}$ \\
\hline $\begin{array}{c}\text { Percentage Enrolled in } \\
\text { Other SUS IHE After } \\
4 \text { Years }\end{array}$ & N/A & $\mathrm{N} / \mathrm{A}$ & $\mathrm{N} / \mathrm{A}$ & $\mathrm{N} / \mathrm{A}$ & $\mathrm{N} / \mathrm{A}$ \\
\hline $\begin{array}{c}\text { TOTAL 4-Year } \\
\text { Success and Progress } \\
\text { Rate (Graduated or } \\
\text { Enrolled in SUS) }\end{array}$ & N/A & $\mathrm{N} / \mathrm{A}$ & $\mathrm{N} / \mathrm{A}$ & N/A & $\mathrm{N} / \mathrm{A}$ \\
\hline
\end{tabular}




\begin{tabular}{|c|c|c|c|c|c|}
\hline $\begin{array}{l}\text { YEAR OF SUS } \\
\text { MATRIC. }\end{array}$ & 2000 & 2001 & 2002 & 2003 & 2004 \\
\hline $\begin{array}{l}\text { Other Transfer Cohort } \\
\text { (Fall/Summer-Fall) } \\
\text { Size }\end{array}$ & N/A & N/A & $\mathrm{N} / \mathrm{A}$ & $\mathrm{N} / \mathrm{A}$ & $\mathrm{N} / \mathrm{A}$ \\
\hline $\begin{array}{l}\text { Percentage Graduated } \\
\text { from Same IHE } \\
\text { Within } 5 \text { Years }\end{array}$ & N/A & N/A & $\mathrm{N} / \mathrm{A}$ & $\mathrm{N} / \mathrm{A}$ & N/A \\
\hline $\begin{array}{l}\text { Percentage Graduated } \\
\text { from Other SUS IHE } \\
\text { Within } 5 \text { Years }\end{array}$ & N/A & $\mathrm{N} / \mathrm{A}$ & $\mathrm{N} / \mathrm{A}$ & $\mathrm{N} / \mathrm{A}$ & $\mathrm{N} / \mathrm{A}$ \\
\hline $\begin{array}{l}\text { Percentage Enrolled in } \\
\text { Same IHE After } 5 \\
\text { Years }\end{array}$ & N/A & N/A & $\mathrm{N} / \mathrm{A}$ & $\mathrm{N} / \mathrm{A}$ & $\mathrm{N} / \mathrm{A}$ \\
\hline $\begin{array}{c}\text { Percentage Enrolled in } \\
\text { Other SUS IHE After } \\
5 \text { Years } \\
\end{array}$ & $\mathrm{N} / \mathrm{A}$ & N/A & $\mathrm{N} / \mathrm{A}$ & $\mathrm{N} / \mathrm{A}$ & $\mathrm{N} / \mathrm{A}$ \\
\hline $\begin{array}{c}\text { TOTAL 5-Year } \\
\text { Success and Progress } \\
\text { Rate (Graduated or } \\
\text { Enrolled in SUS) }\end{array}$ & N/A & $\mathrm{N} / \mathrm{A}$ & $\mathrm{N} / \mathrm{A}$ & $\mathrm{N} / \mathrm{A}$ & $\mathrm{N} / \mathrm{A}$ \\
\hline $\begin{array}{l}\text { 5D. Baccalaureate } \\
\text { Degrees Awarded }\end{array}$ & 2004-2005 & 2005-2006 & 2006-2007 & 2007-2008 & 2008-2009 \\
\hline Baccalaureate Degrees & 160 & 209 & 226 & 233 & 299 \\
\hline $\begin{array}{l}\text { 5E. Baccalaureate } \\
\text { Degrees Awarded in }\end{array}$ & \multicolumn{5}{|c|}{$\begin{array}{l}\text { Areas of Strategic Emphasis: Specific degree programs will be } \\
\text { identified for each university. [UNDUPLICATED COUNT] }\end{array}$} \\
\hline Emphasis & 2004-2005 & 2005-2006 & 2006-2007 & 2007-2008 & 2008-2009 \\
\hline Education & 1 & 0 & 0 & 0 & 0 \\
\hline Health Professions & 0 & 0 & 2 & 1 & 5 \\
\hline $\begin{array}{c}\text { Science, Technology, } \\
\text { Engineering, and } \\
\text { Math }\end{array}$ & 20 & 21 & 17 & 6 & 19 \\
\hline \begin{tabular}{|c|}
$\begin{array}{c}\text { Security \& Emergency } \\
\text { Services }\end{array}$ \\
\end{tabular} & 10 & 20 & 9 & 14 & 21 \\
\hline Globalization & 0 & 2 & 0 & 2 & 1 \\
\hline $\begin{array}{c}\text { Regional Workforce } \\
\text { Needs }\end{array}$ & 33 & 53 & 45 & 51 & 63 \\
\hline $\begin{array}{l}\text { TOTAL: Areas of } \\
\text { Strategic Emphasis }\end{array}$ & 64 & 96 & 73 & 74 & 109 \\
\hline
\end{tabular}




\begin{tabular}{|c|c|c|c|c|c|}
\hline $\begin{array}{c}\text { 5F. Baccalaureate } \\
\text { Degrees Awarded to } \\
\text { Underrepresented } \\
\text { Groups }\end{array}$ & 2004-2005 & 2005-2006 & 2006-2007 & $2007-2008$ & 2008-2009 \\
\hline $\begin{array}{c}\text { \# of Baccalaureate } \\
\text { Degrees Awarded to } \\
\text { Black Non-Hispanic } \\
\text { Students }\end{array}$ & 15 & 17 & 23 & 27 & 35 \\
\hline $\begin{array}{c}\% \text { of Total } \\
\text { Baccalaureate Degrees } \\
\text { (Excluding Those } \\
\text { Awarded to Non- } \\
\text { Resident Aliens and } \\
\text { Unreported) Awarded } \\
\text { to Black Non- } \\
\text { Hispanic Students } \\
\end{array}$ & $9.7 \%$ & $8.4 \%$ & $10.7 \%$ & $11.5 \%$ & $11.9 \%$ \\
\hline $\begin{array}{l}\text { \# of Baccalaureate } \\
\text { Degrees Awarded to } \\
\text { Hispanic Students }\end{array}$ & 9 & 21 & 20 & 24 & 28 \\
\hline $\begin{array}{c}\% \text { of Total } \\
\text { Baccalaureate Degrees } \\
\text { (Excluding Those } \\
\text { Awarded to Non- } \\
\text { Resident Aliens and } \\
\text { Unreported) Awarded } \\
\text { to Hispanic Students }\end{array}$ & $5.8 \%$ & $10.3 \%$ & $9.3 \%$ & $10.2 \%$ & $9.5 \%$ \\
\hline $\begin{array}{c}\text { Number of } \\
\text { Baccalaureate Degrees } \\
\text { Awarded to PELL } \\
\text { Recipients (Defined } \\
\text { as Those Receiving } \\
\text { PELL Within 6 Years } \\
\text { of Graduation) }\end{array}$ & 72 & 79 & 89 & 92 & 104 \\
\hline $\begin{array}{c}\text { \% of Total } \\
\text { Baccalaureate Degrees } \\
\text { (Excluding Those } \\
\text { Awarded to Non- } \\
\text { Resident Aliens) } \\
\text { Awarded to PELL } \\
\text { Recipients (Defined } \\
\text { as Those Receiving } \\
\text { PELL Within } 6 \text { Years } \\
\text { of Graduation) } \\
\end{array}$ & $46.5 \%$ & $38.9 \%$ & $41.2 \%$ & $40.7 \%$ & $35.4 \%$ \\
\hline
\end{tabular}




\begin{tabular}{|c|c|c|c|c|c|}
\hline $\begin{array}{c}\text { 5G. Baccalaureate } \\
\text { Completion Without } \\
\text { Excess Credit Hours }\end{array}$ & 2004-2005 & 2005-2006 & 2006-2007 & 2007-2008 & 2008-2009 \\
\hline $\begin{array}{c}\text { \% of Total } \\
\text { Baccalaureate Degrees } \\
\text { Awarded Within 110\% } \\
\text { of Hours Required for } \\
\text { Degree }\end{array}$ & N/A & N/A & N/A & $70.67 \%$ & $67.28 \%$ \\
\hline $\begin{array}{c}\text { 5H. Undergraduate } \\
\text { Course Offerings }\end{array}$ & Fall 2004 & Fall 2005 & Fall 2006 & Fall 2007 & Fall 2008 \\
\hline $\begin{array}{c}\text { Number of } \\
\text { Undergraduate } \\
\text { Course Sections }\end{array}$ & 88 & 106 & 106 & 107 & 85 \\
\hline $\begin{array}{c}\text { \% of Undergraduate } \\
\text { Course Sections With } \\
<30 \text { Students }\end{array}$ & $77.2 \%$ & $87.7 \%$ & $87.7 \%$ & $73.8 \%$ & $64.7 \%$ \\
\hline $\begin{array}{c}\% \text { of Undergraduate } \\
\text { Course Sections With } \\
>=30 \text { and <50 }\end{array}$ & $20.5 \%$ & $12.1 \%$ & $12.1 \%$ & $26.2 \%$ & $34.1 \%$ \\
\hline $\begin{array}{c}\text { \% of Undergraduate } \\
\text { Course Sections With } \\
\text { >=50 and <100 } \\
\text { Students }\end{array}$ & $2.3 \%$ & $0.0 \%$ & $0.0 \%$ & $0.0 \%$ & $1.2 \%$ \\
\hline $\begin{array}{c}\text { \% of Undergraduate } \\
\text { Course Sections With } \\
\text { >=100 Students }\end{array}$ & $0.0 \%$ & $0.0 \%$ & $0.0 \%$ & $0.0 \%$ & $0.0 \%$ \\
\hline
\end{tabular}




\begin{tabular}{|c|c|c|c|c|c|}
\hline $\begin{array}{l}\text { 5I. Faculty Teaching } \\
\text { Undergraduates }\end{array}$ & 2004-2005 & 2005-2006 & 2006-2007 & 2007-2008 & 2008-2009 \\
\hline $\begin{array}{l}\text { Percentage of Credit } \\
\text { Hours Taught by } \\
\text { Faculty }\end{array}$ & $58.7 \%$ & $68.6 \%$ & $57.0 \%$ & $43.0 \%$ & $39.5 \%$ \\
\hline $\begin{array}{l}\text { Percentage of Credit } \\
\text { Hours Taught by } \\
\text { Adjunct Faculty }\end{array}$ & $40.6 \%$ & $25.6 \%$ & $38.2 \%$ & $55.1 \%$ & $59.5 \%$ \\
\hline $\begin{array}{l}\text { Percentage of Credit } \\
\text { Hours Taught by } \\
\text { Graduate Students }\end{array}$ & $0.7 \%$ & $5.8 \%$ & $4.2 \%$ & $0.1 \%$ & $0.0 \%$ \\
\hline $\begin{array}{l}\text { Percentage of Credit } \\
\text { Hours Taught by } \\
\text { Other Instructors }\end{array}$ & $0.0 \%$ & $0.0 \%$ & $0.6 \%$ & $1.8 \%$ & $1.0 \%$ \\
\hline $\begin{array}{l}\text { 5J. Undergraduate } \\
\text { Instructional Faculty } \\
\text { Compensation }\end{array}$ & Fall 2004 & Fall 2005 & Fall 2006 & Fall 2007 & Fall 2008 \\
\hline $\begin{array}{c}\text { Average Salary and } \\
\text { Benefits for Faculty } \\
\text { Who Teach at Least } \\
\text { One Undergraduate } \\
\text { Course }\end{array}$ & $\$ 80,091$ & $\$ 83,509$ & $\$ 89,184$ & $\$ 92,441$ & $\$ 93,108$ \\
\hline $\begin{array}{l}\text { 5K. Student/Faculty } \\
\text { Ratio }\end{array}$ & 2004-2005 & 2005-2006 & 2006-2007 & $2007-2008$ & 2008-2009 \\
\hline $\begin{array}{c}\text { IPEDS/Common Data } \\
\text { Set Student-to-Faculty } \\
\text { Ratio }\end{array}$ & 21 & 17 & 17 & 17 & 22 \\
\hline $\begin{array}{l}\text { 5L. Licensure Pass } \\
\text { Rates }\end{array}$ & 2004 & 2005 & 2006 & 2007 & 2008 \\
\hline $\begin{array}{c}\text { Nursing: Number of } \\
\text { NCLEX First-Time } \\
\text { Test Takers - } \\
\text { Baccalaureate }\end{array}$ & 0 & 0 & 0 & 0 & 0 \\
\hline $\begin{array}{c}\text { Nursing: Pass Rate } \\
\text { for NCLEX First-Time } \\
\text { Test Takers - } \\
\text { Baccalaureate }\end{array}$ & N/A & N/A & $\mathrm{N} / \mathrm{A}$ & $\mathrm{N} / \mathrm{A}$ & N/A \\
\hline Indicators for pas & $\begin{array}{r}\text { ates on } 0 \\
\text { avai }\end{array}$ & $\begin{array}{l}\text { licensure } \\
\text { e. [See EI }\end{array}$ & $\begin{array}{l}\text { ms will b } \\
\text { JOTES.] }\end{array}$ & ded as da & ecome \\
\hline
\end{tabular}




\begin{tabular}{|c|c|c|}
\hline RM. Tuition Differential & $2008-2009$ & $\begin{array}{c}\text { Sum-Fall } \\
2009\end{array}$ \\
\hline Revenues & -- & - \\
\hline Waivers & 0 & 0 \\
\hline Eligibility & 0 & 0 \\
\hline Number of Students Receiving a Waiver Based on FSAG \\
Eligibility & 0 & 0 \\
\hline Value of Waivers Provided Based on FSAG Eligibility & 0 - & 0 \\
\hline
\end{tabular}

Report on the success of the tuition differential in achieving the articulated purpose.

Include an update on any performance measures that were specified in the BOGapproved tuition differential proposal. [NOTE: In 2009, universities will only be able to report progress for the fall term and reiterate how the university will monitor the longterm success of the tuition differential.]

USF Polytechnic's estimated tuition differential revenue for 2009-2010 was $\$ 82,537$.

Initiatives undertaken included increasing course offerings $(\$ 52,537)$ and increasing the percentage of students in undergraduate majors who are taught by full-time faculty $(\$ 30,000)$.

Targeted program areas for increased course offerings were Business Administration and Information Technology.

$\begin{array}{lll}\text { Business Administration } & 28 & 38 \\ \text { Information Technology } & 22 & 36\end{array}$

In these same targeted program areas, our goal was to increase the number of sections but maintain or improve the percentage of courses taught by full-time faculty. We were more successful in Information Technology, but less successful in Business Administration where we lost four full-time faculty and were able only to replace two.

$\begin{array}{lcc} & \text { Fall 08 \% Courses } & \text { Fall 09\% Courses } \\ \mathrm{T} & \text { Taught by FT Faculty } & \text { Taught by FT Faculty } \\ \text { Business Administration } & 62 \% & 50 \% \\ \text { Information Technology } & 94 \% & 90 \%\end{array}$

We will continue to monitor increases in course offerings in targeted programs and percentage of courses taught by full-time faculty. Over time we will also monitor transfer student retention rate, three year graduation rates for transfer students with an AA degree, student to advisor ratio and student to faculty ratio.

Detailed expenditures of the revenues generated by the tuition differential will be captured in the Operating Budget submission each August. 


\section{6 - Graduate Education Data}

\begin{tabular}{|c|c|c|c|c|c|}
\hline $\begin{array}{l}\text { 6A. GraduateDegree Programs } \\
\text { Implemented or Terminated }\end{array}$ & $\begin{array}{l}\text { New } \\
\text { Program or } \\
\text { Termina- } \\
\text { tion? }\end{array}$ & $\begin{array}{c}\text { Date } \\
\text { Approved by } \\
\text { UBOT }\end{array}$ & $\begin{array}{c}\text { Date } \\
\text { Approved by } \\
\text { BOG, if } \\
\text { Needed }\end{array}$ & $\begin{array}{c}\text { Implementa- } \\
\text { tion Date, if } \\
\text { New }\end{array}$ & $\begin{array}{l}\text { Program CIP } \\
\text { Code }\end{array}$ \\
\hline Marketing -M & New & $5 / 31 / 2007$ & $\mathrm{n} / \mathrm{a}$ & Fall 2008 & 52.1401 \\
\hline 6B. Graduate Degrees Awarded & 2004-2005 & 2005-2006 & 2006-2007 & 2007-2008 & 2008-2009 \\
\hline Master's and Specialist & 113 & 47 & 80 & 66 & 103 \\
\hline Research Doctoral (Total) & 0 & 0 & 0 & 0 & 0 \\
\hline Professional Doctoral (Total) & 0 & 0 & 0 & 0 & 0 \\
\hline Medicine & 0 & 0 & 0 & 0 & 0 \\
\hline Law & 0 & 0 & 0 & 0 & 0 \\
\hline Pharmacy & 0 & \begin{tabular}{l|l}
0 \\
\end{tabular} & 0 & 0 & 0 \\
\hline 6C. Graduate Degrees Awarded & \multicolumn{5}{|c|}{ Areas of Strategic Emphasis: Specific degree programs will be identified } \\
\hline in Areas of Strategic Emphasis & 2004-2005 & $2005-2006$ & 2006-2007 & 2007-2008 & 2008-2009 \\
\hline Education & 21 & 12 & 19 & 22 & 29 \\
\hline Health Professions & 1 & 0 & 0 & 2 & 2 \\
\hline $\begin{array}{c}\text { Science, Technology, } \\
\text { Engineering, and Math }\end{array}$ & 2 & 4 & 1 & 1 & 0 \\
\hline Security \& Emergency Services & 0 & 0 & 0 & 0 & 0 \\
\hline Globalization & 0 & 0 & 0 & 0 & 0 \\
\hline Regional Workforce Needs & 19 & 1 & 3 & 12 & 2 \\
\hline $\begin{array}{c}\text { TOTAL: Areas of Strategic } \\
\text { Emphasis }\end{array}$ & 43 & 17 & 23 & 37 & 33 \\
\hline 6D. Licensure Pass Rates & 2004 & 2005 & 2006 & 2007 & 2008 \\
\hline
\end{tabular}




\section{7 - Research and Economic Development Data}

\begin{tabular}{|c|c|c|c|c|c|}
\hline $\begin{array}{l}\text { 7A. Research and Development } \\
\text { Expenditures }\end{array}$ & 2003-2004 & 2004-2005 & 2005-2006 & 2006-2007 & 2007-2008 \\
\hline $\begin{array}{l}\text { Federally Financed Academic } \\
\text { Research and Development } \\
\text { Expenditures (As Reported in } \\
\text { NSF Surveys) }\end{array}$ & \multirow{3}{*}{\multicolumn{5}{|c|}{$\begin{array}{l}\text { Development/Research data is a USF system-wide } \\
\text { function. Consolidated system data is only available } \\
\text { at this time. }\end{array}$}} \\
\hline $\begin{array}{l}\text { Total Academic Research and } \\
\text { Development Expenditures (As } \\
\text { Reported in NSF Surveys) }\end{array}$ & & & & & \\
\hline $\begin{array}{l}\text { Total Academic Research and } \\
\text { Development Expenditures Per } \\
\text { Full-Time, Tenured, Tenure- } \\
\text { Earning Faculty Member }\end{array}$ & & & & & \\
\hline $\begin{array}{l}\text { 7B. Other Research and Economic } \\
\text { Development Outcomes [for } \\
\text { Entire University] }\end{array}$ & 2003-2004 & 2004-2005 & 2005-2006 & 2006-2007 & 2007-2008 \\
\hline Invention Disclosures Received & \multirow{5}{*}{\multicolumn{5}{|c|}{ DATA ONLY APPLICABLE TO TAMPA CAMPUS }} \\
\hline Total U.S. Patents Issued & & & & & \\
\hline $\begin{array}{c}\text { Patents Issued Per 1,000 Full- } \\
\text { Time, Tenure and Tenure-Earning } \\
\text { Faculty }\end{array}$ & & & & & \\
\hline $\begin{array}{c}\text { Total Number of } \\
\text { Licenses/Options Executed }\end{array}$ & & & & & \\
\hline Total Licensing Income Received & & & & & \\
\hline $\begin{array}{c}\text { Jobs Created By Start-Ups in } \\
\text { Florida }\end{array}$ & \multicolumn{5}{|c|}{$\begin{array}{l}\text { Data collection methodology still under discussion. } \\
\text { (See endnote.) }\end{array}$} \\
\hline
\end{tabular}


7C. Centers of Excellence (Please complete for each Center of Excellence)

Name of Center of Excellence:

From First

Year Up

Most

To Most

Recent

Recent

Year

Year

Research Effectiveness

Competitive Grants Applied For and Received

Total Research Expenditures

Publications in Refereed Journals From Center Research

Professional Presentations Made on Center Research

Invention Disclosures Filed and Issued

Technologies Licensed and Revenues Received

\section{Collaboration Effectiveness}

Collaborations with Other Postsecondary Institutions

Collaborations with K-12 Education Systems/Schools

Collaborations with Private Industry

Students Supported with Center Funds

Students Graduated

Job Placements of Graduates Upon Leaving the Center

Economic Development Effectiveness

Business Start-Ups in Florida

Jobs Created and Jobs Saved in Florida

Specialized Industry Training and Education

Dollars Acquired from Venture Capitalists and Other Investments 


\section{Center of Excellence Narrative Comments [Most Recent Year]}

$\mathrm{N} / \mathrm{A}$

Insert additional pages, as needed for additional Centers.

7D. Commercialization Assistance Grants

Narrative Comments [Most Recent Year]

$\mathrm{N} / \mathrm{A}$

Insert additional pages, as needed for additional grants. 
8 - Voluntary Support of Higher Education*

Endowment Market Value (in 2009 Dollars)

Annual Gifts Received (\$ Amount)

Percentage of Graduates Who Are Alumni Donors
Development/Research data is a USF system-wide function. Consolidated system data is only available at this time.

* Data will be provided by Board staff for institutions that have reported said data through the NACUBO Endowment Study and the CAE Voluntary Support of Education (VSE) Survey.

\section{[INCLUDE ADDITIONAL BACKGROUND DATA ASSOCIATED WITH GRAPHS INCLUDED FOR GOAL \#4.]}

\section{ENDNOTES:}

- Currently, teacher certification examination pass rates are reported for program completers only, resulting in a $100 \%$ pass rate (because state-approved programs require passage of the certification exams for completion). Engineering, accounting, architecture, and other professional licensure data, gathered by the respective licensing boards and housed within the Department of Business and Professional Regulation, are not currently formatted and do not contain sufficient information to match to SUS data. Such a match is necessary to develop metrics reflecting pass rates for graduates in those fields. Board of Governors staff will work with individuals from the appropriate agencies to try to get data in the needed format.

- Board staff are continuing to work with the SUS Technology Transfer Directors to determine the best way to capture consistent information regarding Jobs Created By Start-Ups in Florida in a cost-effective manner.

\section{[Additional definition information will be added to final document.]}


9. Progress on Other Primary Institutional Goals and Metrics As Outlined in the University Work Plan

$P$ rovide a report on progress to date on three - five other primary university goals and metrics that were identified in the institution's last annual work plan/proposal.

[NOTE: In 2009, universities may only be able to identify goals and metrics or report on progress on institutional strategic planning goals already in place.]

SEE WORD DOCUMENT FOR NARRATIVE 